\title{
Mechanisms of the IAA and ACC- deaminase producing strain of Trichoderma longibrachiatum T6 in enhancing wheat seedling tolerance to $\mathrm{NaCl}$ stress
}

Shuwu Zhang ${ }^{1}$, Yantai Gan² and Bingliang Xu*

\begin{abstract}
Background: Trichoderma species, a class of plant beneficial fungi, may provide opportunistic symbionts to induce plant tolerance to abiotic stresses. Here, we determined the possible mechanisms responsible for the indole acetic acid (IAA) and 1-aminocyclopropane-1-carboxylate-deaminase (ACC-deaminase) producing strain of Trichoderma longibrachiatum T6 (TL-6) in promoting wheat (Triticum aestivum L.) growth and enhancing plant tolerance to $\mathrm{NaCl}$ stress.

Results: Wheat treated with or without TL-6 was grown under different levels of salt stress in controlled environmental conditions. TL-6 showed a high level of tolerance to $10 \mathrm{mg} \mathrm{ml}^{-1}$ of $\mathrm{NaCl}$ stress and the inhibitory effect was more pronounced at higher $\mathrm{NaCl}$ concentrations. Under $\mathrm{NaCl}$ stress, the activity of ACC-deaminase and IAA concentration in TL- 6 were promoted, with the activity of ACC-deaminase increased by $26 \%$ at the salt concentration of $10 \mathrm{mg} \mathrm{ml}^{-1}$ and $31 \%$ at $20 \mathrm{mg} \mathrm{ml}^{-1}$, compared with non-saline stress; and the concentration of IAA was increased by 10 and 7\%, respectively $(P<0.05)$. The increased ACC-deaminase and IAA concentration in the TL- 6 strain may serve as an important signal to alleviate the negative effect of $\mathrm{NaCl}$ stress on wheat growth. As such, wheat seedlings with the ACC-deaminase and IAA producing strain of TL- 6 treatment under $\mathrm{NaCl}$ stress increased the IAA concentration by an average of 11\%, decreased the activity of ACC oxidase (ACO) by an average of 12\% and ACC synthase (ACS) 13\%, and decreased the level of ethylene synthesis and the content of ACC by 12 and $22 \%$, respectively $(P<0.05)$. The TL- 6 treatment decreased the transcriptional level of ethylene synthesis genes expression, and increased the IAA production genes expression significantly in wheat seedlings roots; down-regulated the expression of ACO genes by an average of $9 \%$ and ACS genes 12\%, whereas up-regulated the expression of IAA genes by $10 \%(P<0.05)$. TL-6 treatments under NaCl stress decreased the level of $\mathrm{Na}^{+}$accumulation; and increased the uptake of $\mathrm{K}^{+}$and the ratio of $\mathrm{K}^{+} / \mathrm{Na}^{+}$, and the transcriptional level of $\mathrm{Na}^{+} / \mathrm{H}^{+}$antiporter gene expression in both shoots and roots.

Conclusions: Our results indicate that the strain of TL-6 effectively promoted wheat growth and enhanced plant tolerance to $\mathrm{NaCl}$ stress through the increased ACC-deaminase activity and IAA production in TL-6 stain that modulate the IAA and ethylene synthesis, and regulate the transcriptional levels of IAA and ethylene synthesis genes expression in wheat seedling roots under salt stress, and minimize ionic toxicity by disturbing the intracellular ionic homeostasis in the plant cells. These biochemical, physiological and molecular responses helped promote the wheat seedling growth and enhanced plant tolerance to salt stress.
\end{abstract}

Keywords: Trichoderma species, Salt stress, Wheat seedling, Plant growth promotion, 1-aminocyclopropane-1-carboxylatedeaminase, Indole acetic acid, lonic toxicity, Gene expression

\footnotetext{
* Correspondence: xubl@gsau.edu.cn

'Gansu Provincial Key Laboratory of Arid Land Crop Science, Gansu

Agricultural University/College of Plant protection, Gansu Agricultural

University/ Biocontrol Engineering Laboratory of Crop Diseases and Pests of

Gansu Province, Lanzhou 730070, China

Full list of author information is available at the end of the article
}

(c) The Author(s). 2019 Open Access This article is distributed under the terms of the Creative Commons Attribution 4.0 International License (http://creativecommons.org/licenses/by/4.0/), which permits unrestricted use, distribution, and

reproduction in any medium, provided you give appropriate credit to the original author(s) and the source, provide a link to the Creative Commons license, and indicate if changes were made. The Creative Commons Public Domain Dedication waiver (http://creativecommons.org/publicdomain/zero/1.0/) applies to the data made available in this article, unless otherwise stated. 


\section{Background}

Trichoderma spp., a class of soil-borne fungi, is considered a potential bio-control agent effective against plant pathogens and plant parasitic nematodes $[1,2]$. The microorganism often found in rhizsphere can provide beneficial effects on plant growth and yields [3]. The mechanism of Trichoderma spp. promoting plant growth is not clear, but a number of studies with different microorganisms show that some metabolic processes and pathways may be involved. For example, auxin plays an important role in root architecture configuration in association with Trichoderma spp. [4]; the strain $T$. asperellum T203 produces ACC-deaminase that regulates the endogenous ACC level and stimulates root elongation [5] and enhances plant tolerance to abiotic stress [6]; the strain T. virens Gv. 29-8 promotes Arabidopsis growth through auxin response pathway to modulate root development and activate auxin regulated gene expression [4]. Furthermore, plants roots colonized by T. harzianum increased the level of antioxidant enzymes that helped enhance plant resistance to abiotic stresses [7-9]. However, little is known about the synthesis of IAA and ACC-deaminase in Trichoderma longibrachiatum T6 (TL-6) that promotes plant growth and enhances plant tolerance to salt stress. It is unknown whether the function of TL-6 in promoting plant growth and enhancing plant tolerance can be retained under salt stress.

Salinity is one of the important abiotic stresses that limit plant growth and crop yield [10-12]. Globally, saline soil accounts for more than $7 \%$ of the total arable land and the trend of soil salinization has been increasing in recent years [13]. In China, the area of saline soil is greater than 100 million hectare, accounting for about $37 \%$ of the total arable land in the country [14]. In saline soil, plants experience dehydration, nutrient deficiency, membrane dysfunction, and metabolic and photosynthetic activity reduction $[13,15,16]$. To decrease the negative effects of salt stress on plant growth and development, large efforts have been taken in developing salt tolerant plant genotypes through conventional breeding or genetic engineering. However, those efforts have shown limited success as the functional genes responsible for salt tolerance can be lost easily in transgenic plants [17].

An alternative strategy to improve plant tolerance to salt stress is the use of plant growth promoting microbes. Arbuscular mycorrhizal fungi have been reported to enhance the ability of plants to cope with salinity [18-20]. The colonization of arbuscular mycorrhizal fungi helps modulate the ROS-scavenging system in salt-stressed wheat [21]. Also, some Trichoderma species can directly colonize plant roots and stimulate roots growth, and thus, enhance plant tolerance to abiotic stresses [22]. The isolate of T. harzianum was found to help mitigate $\mathrm{NaCl}$ stress in mustard (Brassica juncea L.) through antioxidative defense system [23]. Seed biopriming with the isolate of $T$. harzianum alleviated the negative effects of salinity stress in wheat [11]. In a previous study, we found that application of TL-6 improved wheat tolerance to salt stress [24]. However, our previous study was unable to determine the possible mechanisms responsible for TL-6 promoting wheat seedling growth and enhancing plant tolerance to salt stress, and little is known about whether such function of the TL-6 strain can be retained under different levels of salt stress.

The present study was to test the hypothesis that the TL-6 strain enhancing wheat seedling tolerance to salt stress is through (i) the synthesis of IAA and ACC-deaminase in TL-6 that regulate wheat tolerance to $\mathrm{NaCl}$ stress, (ii) the increased IAA concentration and the enhanced gene expression of transcriptional levels of IAA synthesis, and the decreased ethylene synthesis and the down-regulated gene expression of transcriptional levels of ethylene synthesis in wheat with the TL-6 treatment under $\mathrm{NaCl}$ stress, and (iii) the increased $\mathrm{Na}^{+}$ extrusion and the enhanced gene expression of transcriptional level of $\mathrm{Na}^{+} / \mathrm{H}^{+}$antiporter in wheat by maintaining lower $\mathrm{Na}^{+} / \mathrm{K}^{+}$ratio in wheat that stimulates seedling growth with the application of TL- 6 under $\mathrm{NaCl}$ stress. These determinations will allow an assessment of the mechanisms responsible for TL-6 promoting wheat growth and improving the tolerance to $\mathrm{NaCl}$ stress.

\section{Results}

Effect of $\mathrm{NaCl}$ stress on the colony diameter, spores production and mycelia weight of TL- 6 strain

Measurement of the effect of $\mathrm{NaCl}$ stress on the growth of TL- 6 strain, our results showed that the $\mathrm{NaCl}$ stress treatment had a significant impact on the colony diameter, spores production and mycelia weight of TL-6 strain (Table 1 and Fig. 1). At Days 6 and 7 of salt treatment, the TL- 6 strain tolerated the 0,10 and $20 \mathrm{mg} \mathrm{ml}^{-1}$ of $\mathrm{NaCl}$ stress treatments, but the differential inhibitory effects were observed with the salt concentrations increased to 30,40 and $50 \mathrm{mg} \mathrm{ml}^{-1}$ where the $\mathrm{NaCl}$ treatments significantly decreased the TL-6 growth $(P<0.05)$. At Day 7, the number of spores produced by TL- 6 was significantly higher when treated with the $10 \mathrm{mg} \mathrm{ml}^{-1}$ of $\mathrm{NaCl}$ solution compared with $0 \mathrm{mg} \mathrm{ml}^{-1}$ of $\mathrm{NaCl}$ concentration, but was significantly lower at the concentrations of $\mathrm{NaCl}$ greater than $20 \mathrm{mg} \mathrm{ml}^{-1}$ (Table 1). Also, increased concentrations of $\mathrm{NaCl}$ decreased the dry weight of mycelia significantly at salt concentrations greater than $20 \mathrm{mg} \mathrm{ml}^{-1}$ (Table 1). 
Table 1 Effect of different concentrations of $\mathrm{NaCl}$ solutions on the growth of Trichoderma longibrachiatum T6

\begin{tabular}{|c|c|c|c|c|c|c|c|}
\hline \multirow{3}{*}{$\begin{array}{l}\text { Salt concentrations } \\
\left(\mathrm{mg} \mathrm{ml}^{-1}\right)\end{array}$} & \multicolumn{5}{|c|}{ Days in incubation (d) } & \multirow{3}{*}{$\begin{array}{l}\text { Number of spores } \\
\text { produced } \\
\left(10^{6} \text { spores } \mathrm{ml}^{-1}\right)\end{array}$} & \multirow{3}{*}{$\begin{array}{l}\text { Mycelia dry } \\
\text { weight (g) }\end{array}$} \\
\hline & 3 & 4 & 5 & 6 & 7 & & \\
\hline & \multicolumn{5}{|c|}{ Colony diameter $(\mathrm{cm})$} & & \\
\hline 0 & $6.8 \pm 0.2^{\mathrm{a}}$ & $9.0 \pm 0.0^{\mathrm{a}}$ & $9.0 \pm 0.0^{\mathrm{a}}$ & $9.0 \pm 0.0^{\mathrm{a}}$ & $9.0 \pm 0.0^{\mathrm{a}}$ & $27.3 \pm 1.2^{b}$ & $0.193 \pm 0.010^{2}$ \\
\hline 10 & $5.0 \pm 0.3^{\mathrm{ab}}$ & $7.3 \pm 0.2^{\mathrm{ab}}$ & $9.0 \pm 0.0^{\mathrm{a}}$ & $9.0 \pm 0.0^{\mathrm{a}}$ & $9.0 \pm 0.0^{\mathrm{a}}$ & $29.3 \pm 1.1^{\mathrm{a}}$ & $0.192 \pm 0.007^{\circ}$ \\
\hline 20 & $3.8 \pm 0.3^{b}$ & $5.5 \pm 0.3^{b}$ & $8.4 \pm 0.2^{\mathrm{a}}$ & $9.0 \pm 0.0^{\mathrm{a}}$ & $9.0 \pm 0.0^{\mathrm{a}}$ & $15.0 \pm 0.9^{c}$ & $0.175 \pm 0.008^{h}$ \\
\hline 30 & $2.4 \pm 0.2^{c}$ & $3.6 \pm 0.3^{c}$ & $5.3 \pm 0.3^{b}$ & $6.5 \pm 0.3^{b}$ & $7.1 \pm 0.3^{b}$ & $4.5 \pm 0.2^{d}$ & $0.123 \pm 0.003$ \\
\hline 40 & $1.4 \pm 0.1^{\mathrm{cd}}$ & $1.9 \pm 0.2^{d}$ & $2.5 \pm 0.2^{c}$ & $3.0 \pm 0.1^{c}$ & $3.5 \pm 0.3^{c}$ & $0.1 \pm 0.02^{\mathrm{e}}$ & $0.086 \pm 0.005^{\circ}$ \\
\hline 50 & $0.9 \pm 0.04^{d}$ & $1.4 \pm 0.2^{d}$ & $1.8 \pm 0.3^{c}$ & $2.1 \pm 0.2^{c}$ & $2.7 \pm 0.2^{d}$ & $0.07 \pm 0.01^{e}$ & $0.076 \pm 0.003^{\circ}$ \\
\hline
\end{tabular}

Data are mean \pm standard error of replicates, and the number of spore production was determined 7 days after treatment, the mycelia dry weight was determined 5 days after inoculation. Different letters in the same column mean significant difference at the $P<0.05$ level by Duncan's new multiple range test $(n=12)$

\section{Determination of IAA production and ACC-deaminase activity in TL-6}

The concentration of IAA and the activity of ACCdeaminase in TL-6 were determined under different levels of $\mathrm{NaCl}$ concentrations. The strain of TL-6 produced both IAA (Fig. 2a) and ACC-deaminase (Fig. 2b) regardless of $\mathrm{NaCl}$ concentration. However, the amounts of IAA produced by TL- 6 at the $\mathrm{NaCl}$ concentrations of 10 and $20 \mathrm{mg} \mathrm{ml}^{-1}$ were significantly higher (by 10 and 7\%) compared with $0 \mathrm{mg} \mathrm{ml}^{-1}$ of $\mathrm{NaCl}$ concentration (Fig. 2a) $(P<0.05)$. In contrast to IAA, the activity of ACCdeaminase differed significantly with the $\mathrm{NaCl}$ concentration (Fig. 2b) $(P<0.05)$. Compared with $0 \mathrm{mg} \mathrm{ml}^{-1}$ of $\mathrm{NaCl}$ concentration, the $\mathrm{NaCl}$ treatment at $10 \mathrm{mg} \mathrm{ml}^{-1}$ increased the activity of ACC-deaminase by $26 \%$, and the doubling $\mathrm{NaCl}$ concentration to $20 \mathrm{mg} \mathrm{ml}^{-1}$ increased the activity of ACC-deaminase by $31 \%(P<0.05)$.

\section{IAA production in wheat seedling}

Wheat seedlings with the IAA and ACC-deaminase producing strain of TL- 6 treatment under $\mathrm{NaCl}$ stress increased the IAA concentration significantly in wheat seedlings roots $(P<0.05)$. At each of the three $\mathrm{NaCl}$ levels, the wheat seedlings treated with the IAA and ACC-deaminase producing strain of TL-6 significantly increased the level of IAA concentration compared with sterile water treatment; the IAA concentration was increased by $6 \%\left(0 \mathrm{mg} \mathrm{ml}^{-1}\right), 14 \%\left(10 \mathrm{mg} \mathrm{ml}^{-1}\right)$ and $13 \%\left(20 \mathrm{mg} \mathrm{ml}^{-1}\right)$ in wheat seedlings roots, respectively $(P<0.05)$. However, in the sterile water treatment, the IAA concentration from wheat seedlings roots was decreased by $13 \%$ at the $10 \mathrm{mg} \mathrm{ml}^{-1}$ of $\mathrm{NaCl}$ concentration and by $16 \%$ at the $20 \mathrm{mg} \mathrm{ml}^{-1}$ of $\mathrm{NaCl}$ stress, compared with $0 \mathrm{mg} \mathrm{ml}^{-1}$ of $\mathrm{NaCl}$ concentration $(P<0.05)$ (Fig. 3a).

\section{Effect of TL-6 on the relative transcript level of IAA} synthesis gene expression in wheat seedling

The IAA and ACC-deaminase producing strain of TL-6 treatment increased the IAA production genes expression significantly in wheat seedlings roots under $\mathrm{NaCl}$ stress $(P<0.05)$. Compared to $0 \mathrm{mg} \mathrm{ml}^{-1} \mathrm{NaCl}$ stressed plants in sterile water treatment, $\mathrm{NaCl}$ stress (10 and $20 \mathrm{mg} \mathrm{ml}^{-1}$ ) decreased the transcript levels of the TaTGW6 (Fig. 3b) and TaIAGLU (Fig. 3c) genes expression in sterile water treatment, but the transcript levels of the TaTGW6 (Fig. 3b) and TaIAGLU (Fig. 3c) genes expression were up-regulated significantly in wheat seedlings roots treated with the IAA and ACC-deaminase producing strain of TL-6 under each

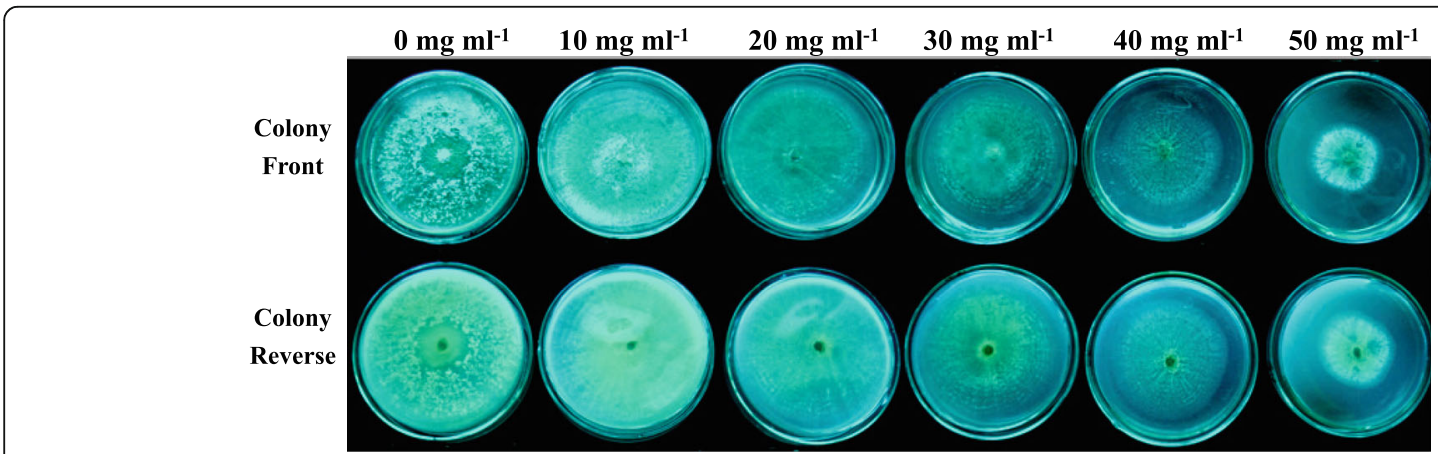

Fig. 1 Colony growth of Trichoderma longibrachiatum T6 under the different $\left(0,10,20,30,40\right.$, and $50 \mathrm{mg} \mathrm{ml}^{-1}$ ) concentrations of NaCl solutions 7 days after treatment at $25^{\circ} \mathrm{C}$ 


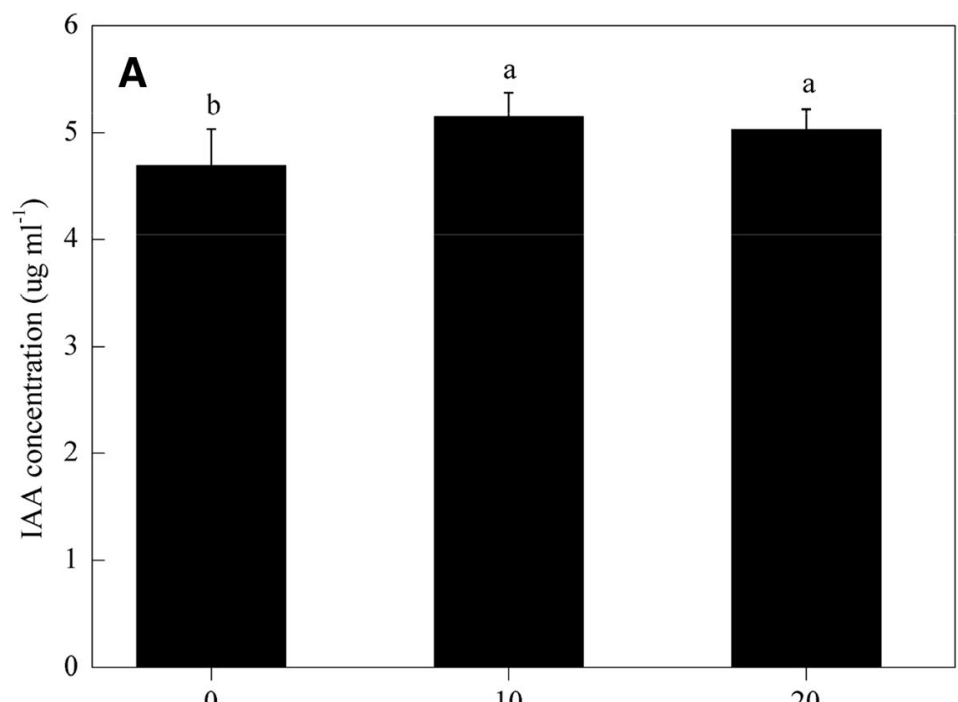

0

10

20

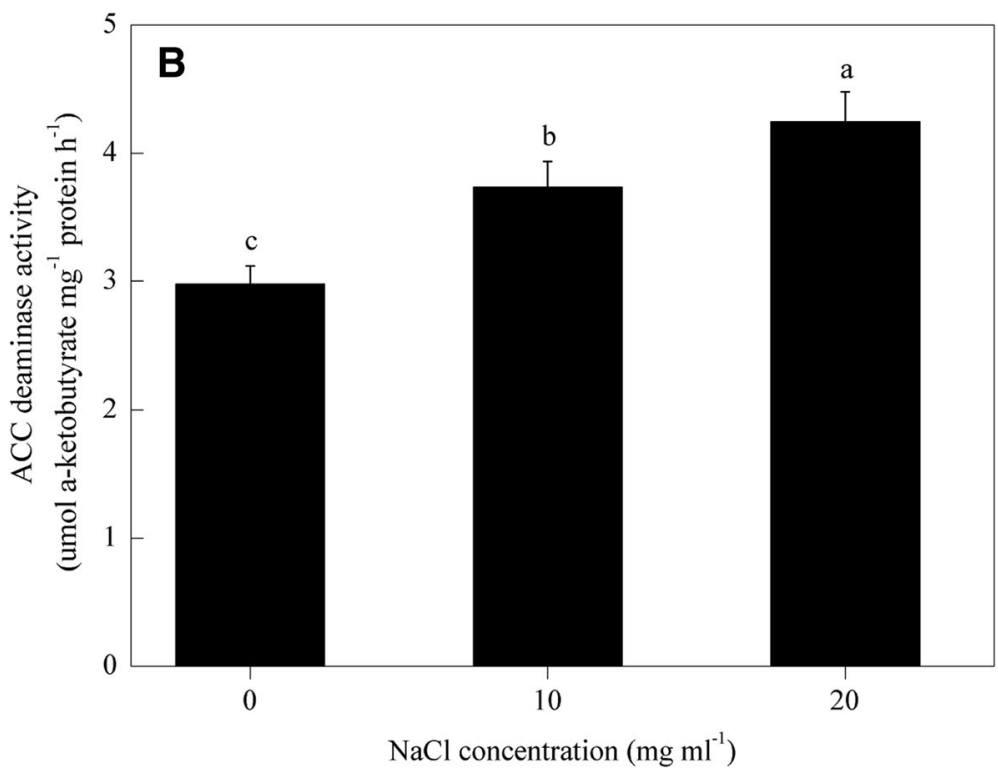

Fig. 2 Effect of different concentrations of $\mathrm{NaCl}$ solutions on (a) IAA concentration and (b) the activity of ACC-deaminase in Trichoderma longibrachiatum T6. The line bars represent the standard errors of the means. Different letters denote significant difference at the $P<0.05$ level by Duncan's new multiple range test $(n=12)$

of the three $\mathrm{NaCl}$ levels $(P<0.05)$. TaTGW6 gene expression in wheat seedling roots was up-regulated under salt stress $\left(0,10\right.$ and $\left.20 \mathrm{mg} \mathrm{ml}^{-1}\right)$ by 6,13 , and $17 \%$ (Fig. 3b), and TaIAGLU gene by 6,9 , and $11 \%$ (Fig. 3c), respectively, after treated with the IAA and ACC-deaminase producing strain of TL-6, compared to the sterile water treatment $(P<0.05)$.

\section{ACO and ACS activity in wheat seedling}

Wheat seedlings with the IAA and ACC-deaminase producing strain of TL-6 treatment under $\mathrm{NaCl}$ stress decreased the activity of ACO and ACS significantly in wheat seedlings roots $(P<0.05)$. Measured at Day 35, the seedlings treated with the IAA and ACC-deaminase producing strain of TL- 6 decreased the activity of ACO by $10 \%$ at the $\mathrm{NaCl}$ concentration of $0 \mathrm{mg} \mathrm{ml}^{-1}$, furthered to $13 \%$ at $10 \mathrm{mg} \mathrm{ml}^{-1}$ and $14 \%$ at $20 \mathrm{mg} \mathrm{ml}^{-1}$ (Fig. 4a), whereas the TL- 6 treatment decreased the activity of ACS by 5, 14 and $20 \%$ (Fig. 4b), respectively, compared with sterile water treatment $(P<0.05)$. However, the activity of ACO and ACS in wheat seedlings roots treated with sterile water was increased significantly with the increase of $\mathrm{NaCl}$ concentrations from 0 to $20 \mathrm{mg} \mathrm{ml}^{-1}(P<0.05)$. The activity of ACO was increased by 9 to $13 \%$ (Fig. 4a) and the activity of ACS was increased by 12 to $34 \%$ (Fig. 4b) with the $\mathrm{NaCl}$ 

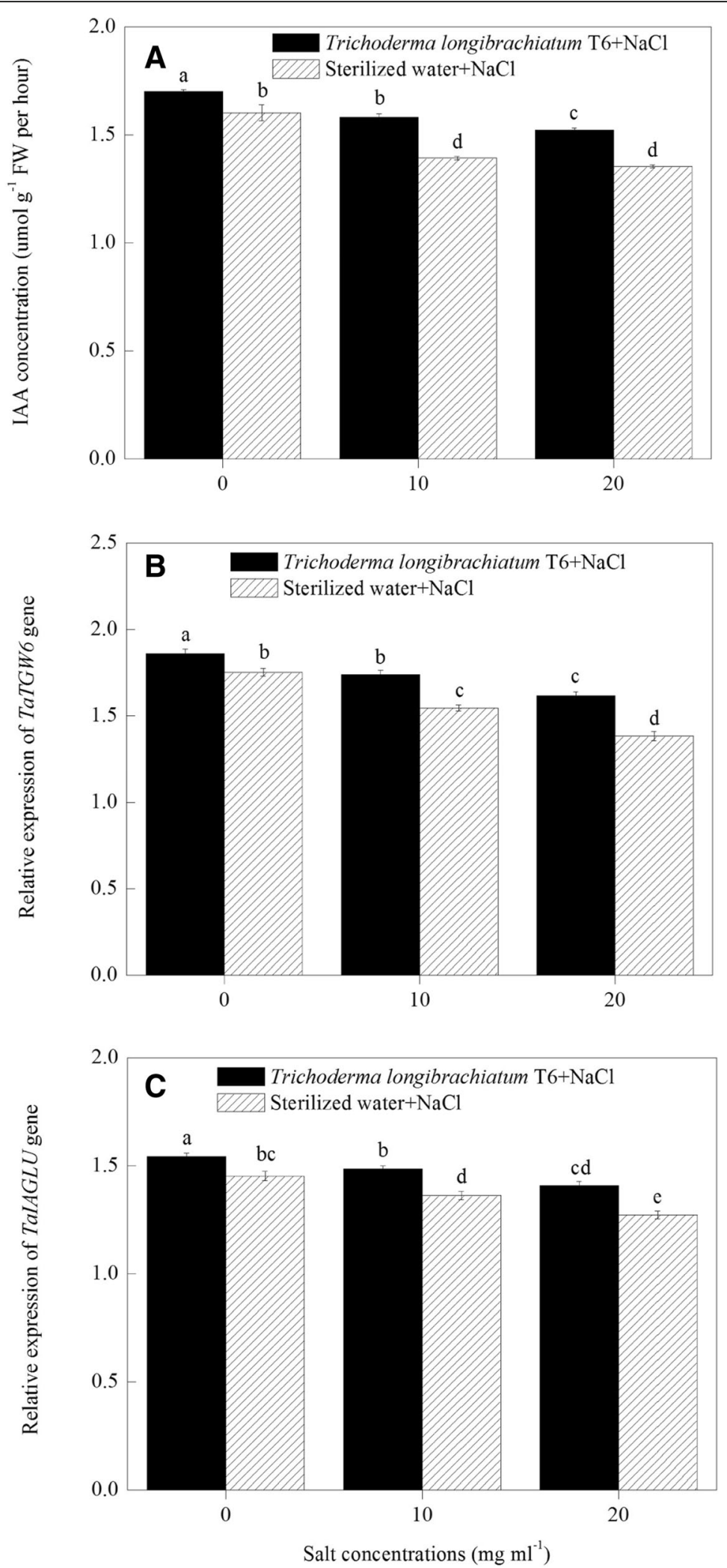

Fig. 3 (See legend on next page.) 
(See figure on previous page.)

Fig. 3 Effect of the strain of Trichoderma longibrachiatum T6 on (a) IAA production, and (b) the expression of TaTGW6 and (c) TalAGLU genes in wheat seedling roots under $\mathrm{NaCl}$ stress. The line bars represent the standard errors of the means. Different letters denote significant difference at the $P<0.05$ level by Duncan's new multiple range test $(n=12)$. In the three TL-6 treatments, wheat seeds were presoaked with the suspension of TL-6 spores for $12 \mathrm{~h}$, whereas in the three sterile water treatments, wheat seeds were presoaked with sterile water only

solution increasing from 10 to $20 \mathrm{mg} \mathrm{ml}^{-1}$, compared with $0 \mathrm{mg} \mathrm{ml}^{-1}$ of $\mathrm{NaCl}$ concentration under sterile water treatment $(P<0.05)$.

\section{ACC content and ethylene synthesis in wheat seedling} ACC content and ethylene synthesis in wheat seedlings roots were determined under different levels of $\mathrm{NaCl}$ stress after the application of the IAA and ACC-deaminase producing strain of TL-6 or sterile water. The content of ACC in wheat seedlings roots significantly increased after treated with the $\mathrm{NaCl}$ solution increasing from 10 to $20 \mathrm{mg} \mathrm{m}^{-1}$ under sterile water treatment. In the wheat roots, the content of ACC was increased by 25 to $37 \%$, compared with $0 \mathrm{mg} \mathrm{ml}^{-1}$ of $\mathrm{NaCl}$ concentration under sterile water treatment $(P<0.05)$ (Fig. 5a). However, application of IAA and ACC-deaminase
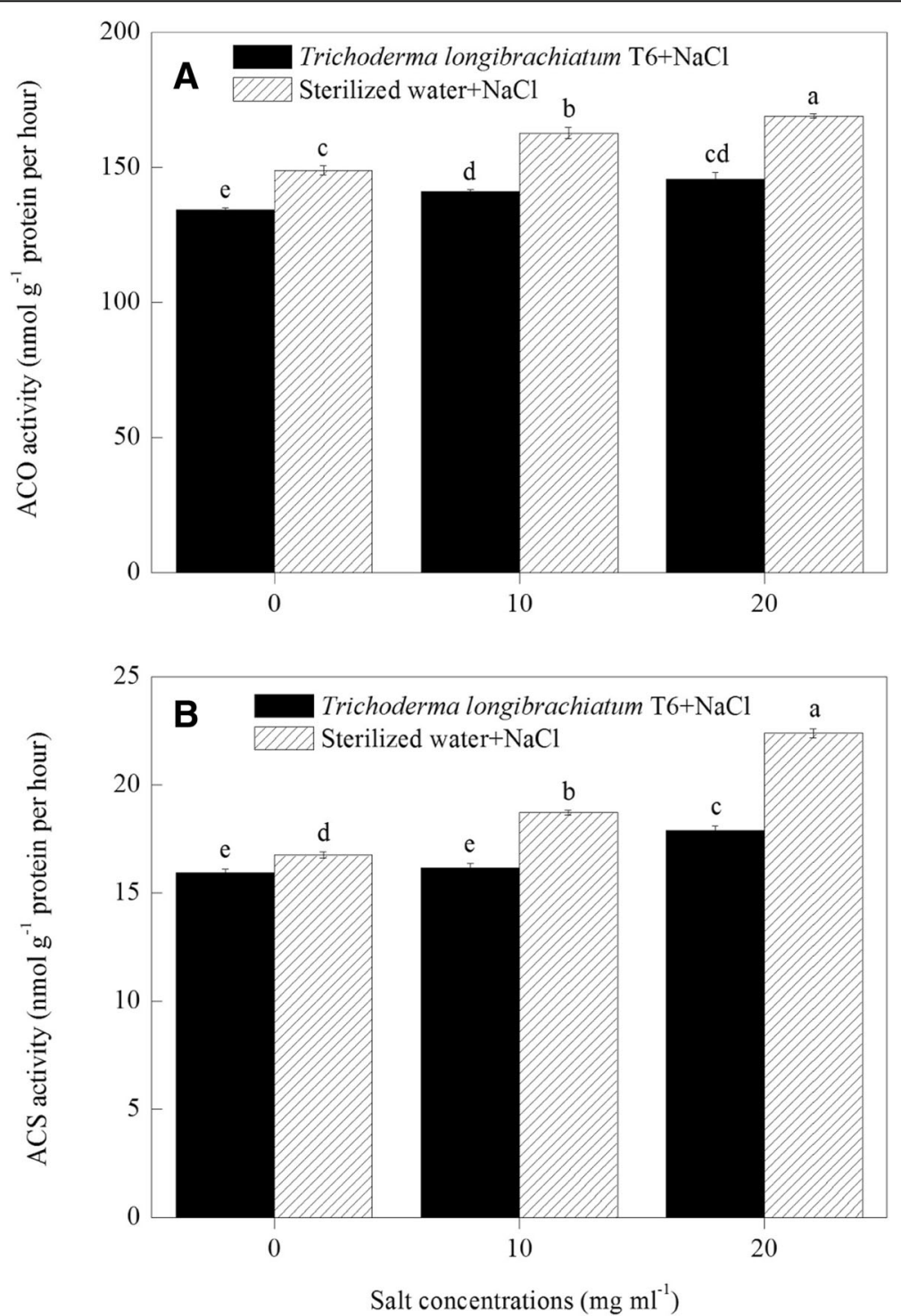

Fig. 4 Effect of the strain of Trichoderma longibrachiatum T6 on (a) ACO activity and (b) the activity of ACS in wheat seedling roots under NaCl stress. The line bars represent the standard errors of the means. Different letters denote significant difference at the $P<0.05$ level by Duncan's new multiple range test $(n=12)$. The treatments are detailed in the footnote of Fig. 3 

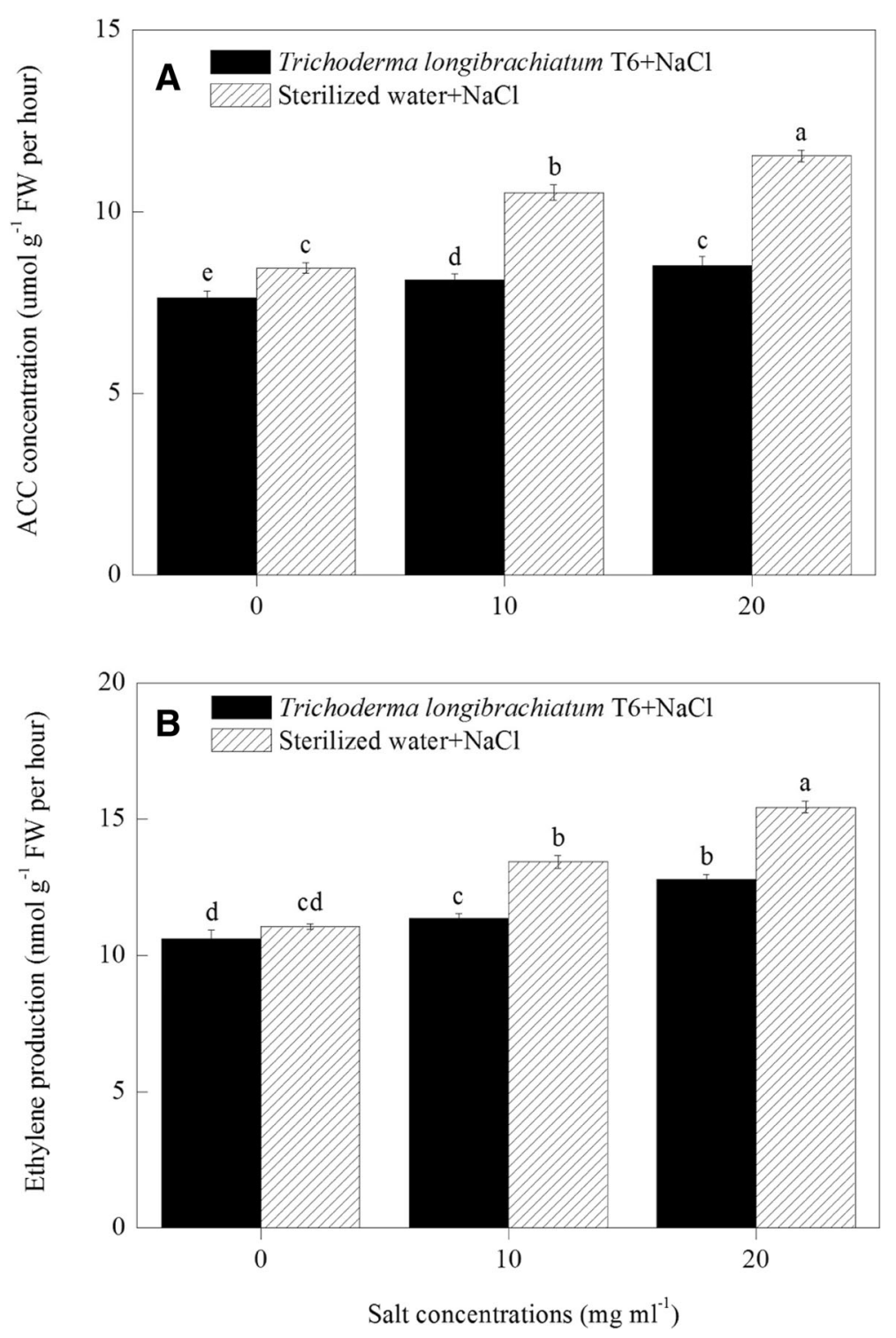

Fig. 5 Effect of the strain of Trichoderma longibrachiatum T6 on (a) ACC content and (b) ethylene production in wheat seedling roots under NaCl stress. The line bars represent the standard errors of the means. Different letters denote significant difference at the $P<0.05$ level by Duncan's new multiple range test $(n=12)$. The treatments are detailed in the footnote of Fig. 3

producing strain of TL-6 significantly decreased the content of ACC in the wheat seedlings roots under salt stress, compared with sterile water treatment. The content of ACC was decreased by $10 \%$ at the $\mathrm{NaCl}$ concentration of $0 \mathrm{mg} \mathrm{ml}^{-1}$, furthered to $29 \%$ at $10 \mathrm{mg} \mathrm{ml}^{-1}$ and $26 \%$ at 20 $\mathrm{mg} \mathrm{ml}^{-1}$, compared with sterile water treatment $(P<$ $0.05)$. These results showed that the application of the IAA and ACC-deaminase producing strain of TL-6 decreased the content of ACC in wheat seedlings roots.

In addition, in the sterile water treatment, the ethylene production in wheat seedlings was $22 \%$ greater at $10 \mathrm{mg}$ $\mathrm{ml}^{-1}$ of $\mathrm{NaCl}$ concentration and was $40 \%$ greater at 20 $\mathrm{mg} \mathrm{ml}^{-1}$, compared with $0 \mathrm{mg} \mathrm{ml}^{-1}$ of $\mathrm{NaCl}$ concentration
$(P<0.05)$ (Fig. 5b). Regardless of the salt level, the wheat seedlings treated with the IAA and ACC-deaminase producing strain of TL-6 decreased the ethylene production significantly compared with the sterile water treatment. Averaged across the three $\left(0,10,20 \mathrm{mg} \mathrm{ml}^{-1}\right) \mathrm{NaCl}$ levels, the wheat seedlings treated with TL- 6 decreased the ethylene production by $12 \%$ compared with sterile water treatment $(P<0.05)$ (Fig. 5b).

Effect of TL-6 on the relative transcript level of ethylene synthesis gene expression in wheat seedling

The TL-6 treatment decreased the transcriptional level of ethylene synthesis genes expression significantly in 
wheat seedlings roots under $\mathrm{NaCl}$ stress $(P<0.05)$. Compared to the control plants, there were higher levels of TaACO (Fig. 6a), TaACO1 (Fig. 6b), TaACO2 (Fig. 6c), TaACS (Fig. 6d), TaACS1 (Fig. 6e) and TaACS7 (Fig. 6f) genes expression in wheat seedlings roots after being induced by $\mathrm{NaCl}$ stress in the sterile water treatment. In contrast, at each of the three $\mathrm{NaCl}$ levels $(0,10,20 \mathrm{mg}$ $\mathrm{ml}^{-1}$ ), the application of IAA and ACC-deaminase producing strain of TL-6 led to the transcript levels of TaACO (Fig. 6a), TaACO1 (Fig. 6b), TaACO2 (Fig. 6c), TaACS (Fig. 6d), TaACS1 (Fig. 6e) and TaACS7 (Fig. 6f) genes were down-regulated expression compared with sterile water treatment.

\section{Effect of TL- 6 on $\mathrm{Na}^{+}$and $\mathrm{K}^{+}$concentration in wheat seedling under $\mathrm{NaCl}$ stress}

The $\mathrm{Na}^{+}$and $\mathrm{K}^{+}$concentration in wheat seedling were measured at Day 35 under $\mathrm{NaCl}$ stress after the application of the IAA and ACC-deaminase producing strain of TL- 6 or sterile water. Compared to the $0 \mathrm{mg} \mathrm{ml}^{-1} \mathrm{NaCl}$ stressed plants, the concentration of $\mathrm{Na}^{+}$was significantly increased in wheat seedling shoots and roots under 10 and $20 \mathrm{mg} \mathrm{ml}^{-1} \mathrm{NaCl}$ stress, whereas the concentration of $\mathrm{K}^{+}$and the ratio of $\mathrm{K}^{+} / \mathrm{Na}^{+}$were decreased with increasing of salt concentrations in the sterile water treatment $(P<0.05)$ (Fig. 7). In contrast, significant differences were observed and detected between the sterile water and TL-6 treatments with respect to $\mathrm{Na}^{+}$and $\mathrm{K}^{+}$/ $\mathrm{Na}^{+}$ratio in the shoots and roots of wheat seedling under 0,10 and $20 \mathrm{mg} \mathrm{ml}^{-1} \mathrm{NaCl}$ stress. A significant decrease in $\mathrm{Na}^{+}$concentration and increase in $\mathrm{K}^{+} / \mathrm{Na}^{+}$ ratio, and also slight increase in $\mathrm{K}^{+}$absorption were observed in the shoots and roots after the application of the IAA and ACC-deaminase producing strain of TL-6 under 0,10 and $20 \mathrm{mg} \mathrm{ml}^{-1} \mathrm{NaCl}$ stress in comparison to the sterile water treatment $(P<0.05)$. Pretreatment with the IAA and ACC-deaminase producing strain of TL-6 significantly decreased the $\mathrm{Na}^{+}$concentration in shoots by $27 \%$ at the $0 \mathrm{mg} \mathrm{ml}^{-1}$ of $\mathrm{NaCl}$ treatment, $39 \%$ at $10 \mathrm{mg} \mathrm{ml}^{-1}$ and $33 \%$ at $20 \mathrm{mg} \mathrm{ml}^{-1}$ (Fig. 7a), and roots by 28,34 , and $41 \%$ (Fig. $7 \mathrm{~b}$ ), respectively; as well as the $\mathrm{K}^{+}$concentration in roots was increased by 4,6 , and $8 \%$ (Fig. 7c) with 0,10 and $20 \mathrm{mg} \mathrm{ml}^{-1} \mathrm{NaCl}$ stress, respectively, and also roots by 6,8 , and $5 \%$ (Fig. $7 \mathrm{~d}$ ), respectively $(P<0.05)$. Similarly, the ratio of $\mathrm{K}^{+} / \mathrm{Na}^{+}$in the shoots of wheat seedling was increased by 43,75 , and $63 \%$ (Fig. 7e) with 0,10 and $20 \mathrm{mg} \mathrm{ml}^{-1} \mathrm{NaCl}$ stress and also in roots were increased by 47,66 , and $79 \%$, respectively $(P<0.05)$ (Fig. 7f).

\section{Effect of TL-6 on SOS1 relative transcript level in wheat seedling}

Our results indicate that SOS1 gene plays an important role in regulating the $\mathrm{Na}^{+}$transportation under salt stress, and alleviating the $\mathrm{Na}^{+}$damage effects in wheat seedling shoots and roots (Fig. 8). Compared to the 0 $\mathrm{mg} \mathrm{ml}^{-1} \mathrm{NaCl}$ stressed plants, SOS1 gene expression was up-regulated in wheat seedling shoots and roots under salt stress $\left(10\right.$ and $\left.20 \mathrm{mg} \mathrm{ml}^{-1}\right)$ in the sterile water treatment. At each of the three $\mathrm{NaCl}$ levels $(0,10,20$ $\mathrm{mg} \mathrm{ml}^{-1}$ ), the transcript level of SOS1 gene in wheat seedling shoots and roots treated with the IAA and ACC-deaminase producing strain of TL- 6 was significantly higher than those of sterile water treatment. SOS1 gene expression in wheat seedling shoots was up-regulated under salt stress $\left(0,10\right.$ and $\left.20 \mathrm{mg} \mathrm{ml}^{-1}\right)$ by 13, 36, and $38 \%$ (Fig. 8a), and roots by 7,22 , and $39 \%$ (Fig. 8b), respectively, after treated with the beneficial strain of TL-6, compared to the sterile water treatment $(P<0.05)$.

\section{Discussion}

Trichoderma strains are free-living fungi in soil and can colonize plant roots and promote plant growth $[4,25]$. A number of mechanisms for Trichoderma spp. promoting plant growth have been proposed [25], but there is little information available in regard to the mechanisms of Trichoderma longibrachiatum T6 (TL-6) promotes wheat growth and enhances plant tolerance to different levels of $\mathrm{NaCl}$ stress. The present study, through a series of in vitro and greenhouse experiments, determined the potential of TL- 6 in tolerance to salt stress and the mechanisms of TL- 6 promoting wheat seedling growth under various levels of salt stress. Our results showed that TL-6 promoted plant growth under saline condition largely through the increase of the activity of ACC-deaminase and the level of IAA production in TL-6 strain that induce the expression of genes encoding IAA as well as the level of IAA production, decrease the expression of genes encoding ethylene synthesis as well as the activity of ACO and ACS, and the content of ACC and the level of ethylene synthesis in wheat seedlings; alleviate the $\mathrm{Na}^{+}$damage effects and enhance the transcriptional level of $\mathrm{Na}^{+} / \mathrm{H}^{+}$antiporter gene expression in wheat plants. These improvements serve as the main mechanisms responsible for the IAA and ACC-deaminase producing strain of TL-6 promoting plant growth and enhancing salt tolerance in wheat.

High salinity decreases the growth of plants and the magnitude of this effect may be related to the interaction among the host, microbe, and the level of salt stress $[22,25]$. Thus, it is of importance to determine whether different concentrations of $\mathrm{NaCl}$ solutions present a negative effect on the growth of TL-6. Our study showed that the low concentrations of $\mathrm{NaCl}$ had no negative effect on the growth of TL-6, and in fact a $10 \mathrm{mg} \mathrm{ml}^{-1}$ of $\mathrm{NaCl}$ solution enhanced the TL-6 strain growth (both the diameter and the 


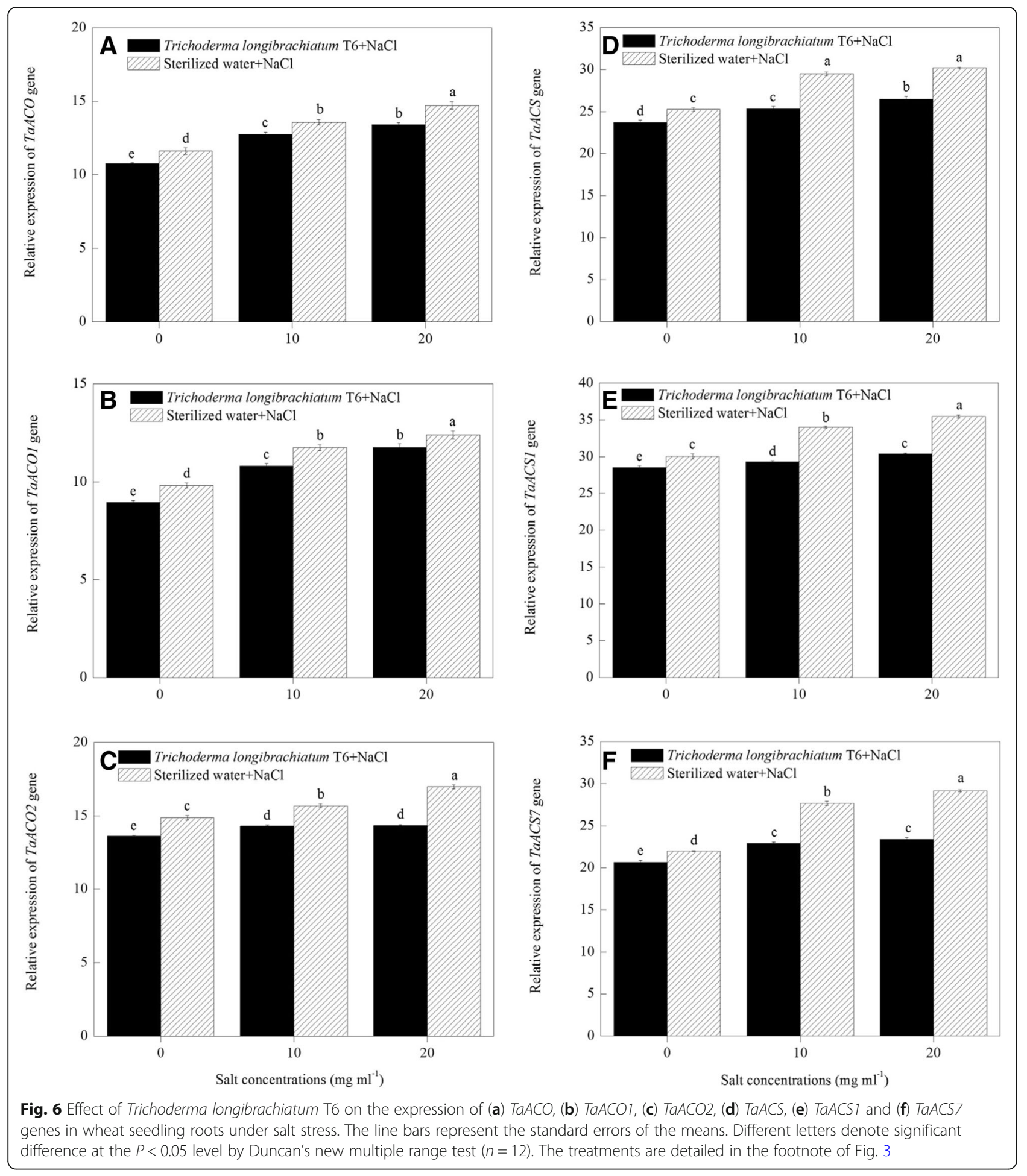

number of TL-6 spores) in comparison to those under non-saline condition. $\mathrm{A} \mathrm{NaCl}$ concentrations greater than $20 \mathrm{mg} \mathrm{ml}^{-1}$ significantly decreased the TL-6 strain growth, spores production and mycelia dry weight. This indicates that the effect of $\mathrm{NaCl}$ on the growth of TL-6 is in a dose-dependent manner, with high salinity inhibiting the growth, and low salinity promoting its growth [26]. In a study, Contreras-Cornejo et al. [27] found that salt stress decreased the growth of Trichoderma spp. in a dose-dependent manner, where the strains tolerated 8.8 $\mathrm{mg} \mathrm{ml}^{-1}$ of $\mathrm{NaCl}$ stress, but the growth of strains was decreased significantly with the salt concentration 

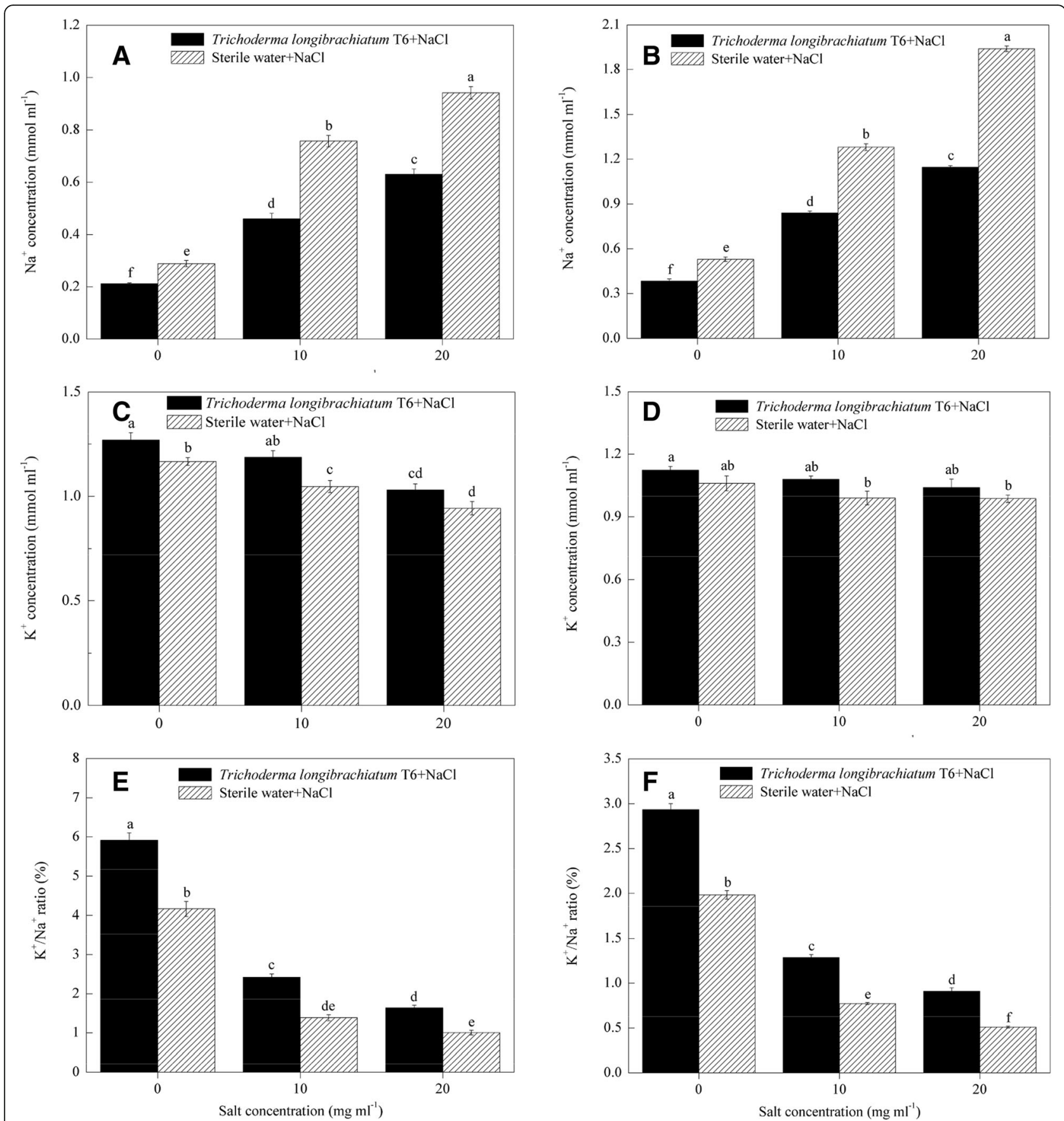

Fig. 7 Effect of the strain of Trichoderma longibrachiatum $\mathrm{T} 6 \mathrm{on} \mathrm{Na}^{+}(\mathbf{a}$ and $\mathbf{b})$ and $\mathrm{K}^{+}(\mathbf{c}$ and $\mathbf{d})$ concentration, and $\mathrm{K}^{+} / \mathrm{Na}^{+}$ratio $(\mathbf{e}$ and $\mathbf{f})$ in wheat seedling under $\mathrm{NaCl}$ stress. Where $\mathbf{a}, \mathbf{c}$ and $\mathbf{e}$ represent $\mathrm{Na}^{+}$and $\mathrm{K}^{+}$concentration, and $\mathrm{K}^{+} / \mathrm{Na}^{+}$ratio in the shoot of wheat seedling; $\mathbf{b}$, $\mathbf{d}$ and $\mathbf{f}$ represent $\mathrm{Na}^{+}$and $\mathrm{K}^{+}$concentration, and $\mathrm{K}^{+} / \mathrm{Na}^{+}$ratio in the root of wheat seedling. The line bars represent the standard errors of the means. Different letters denote significant difference at the $P<0.05$ level by Duncan's new multiple range test $(n=12)$. The treatments are detailed in the footnote of Fig. 3

increased to $17.6 \mathrm{mg} \mathrm{ml}^{-1}$. High salt concentrations may enhance the water potential of the substrate that reduces the growth of fungal colonies [28]. Also, high salt may affect cytoplasmic metabolic activity, such as intracellular proteins which may provide the extra osmotic potential to prevent plasmolysis [29]. Our results indicate that a dose of salt lower than $20 \mathrm{mg}$ $\mathrm{ml}^{-1}$ is adequate to determine the response of wheat plants to salt stress at the presence of Trichoderma spp. 

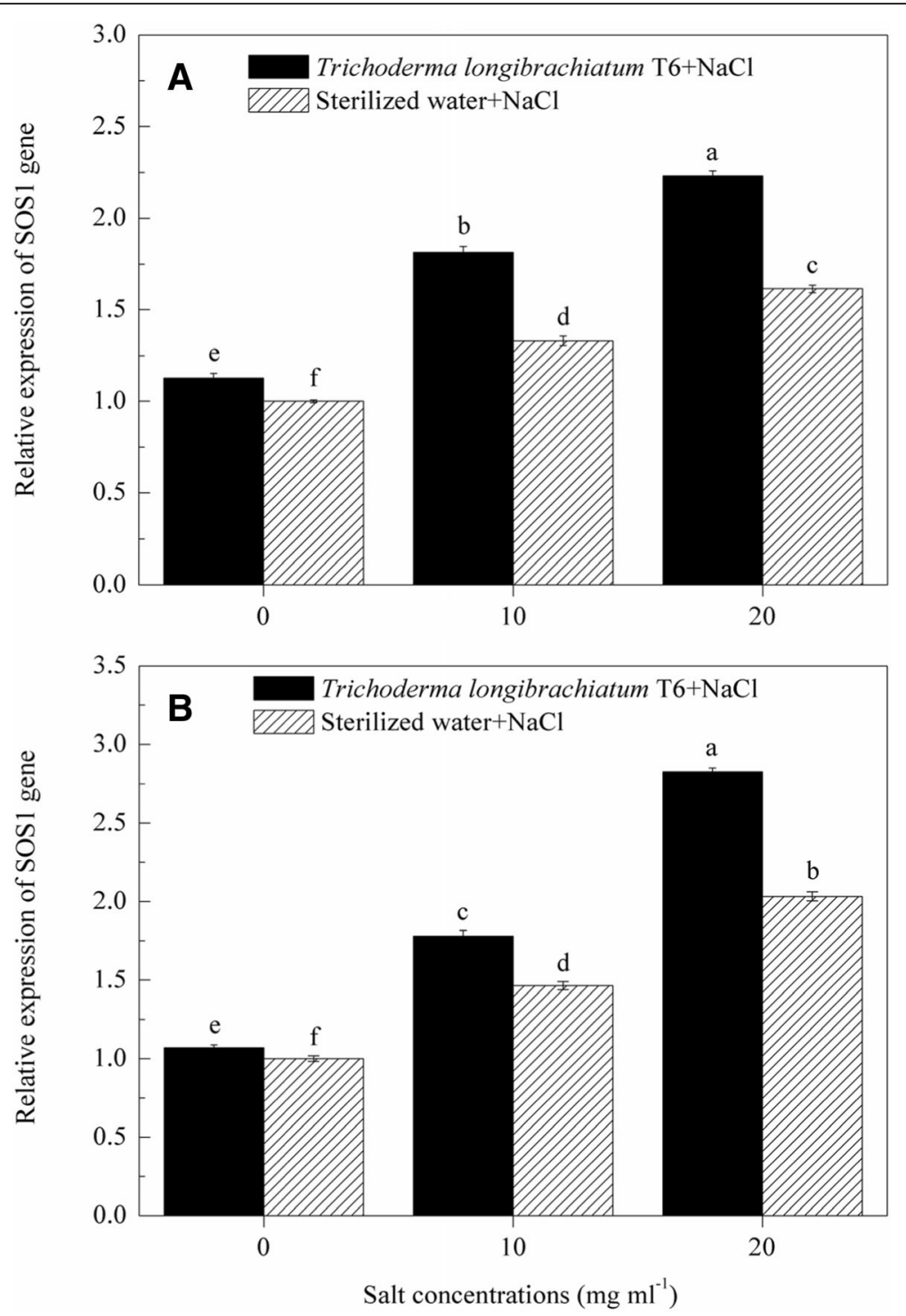

Fig. 8 Effect of Trichoderma longibrachiatum T6 on the expression of SOS1 gene in wheat seedlings shoot (a) and root (b) under salt stress. The line bars represent the standard errors of the means. Different letters denote significant difference at the $P<0.05$ level by Duncan's new multiple range test $(n=12)$. The treatments are detailed in the footnote of Fig. 3

In cucumber (Cucumis sativus L.), the use of T. asperellum Q1 strain promoted the plant growth due to the increased production of siderophore and auxin, and the enhanced activity of ACC-deaminase and phosphate solubilization [13]. However, little information is available regarding to the production of auxin and the activity of ACC-deaminase in TL-6 under salt stress. An unknown question was whether or not IAA and ACC-deaminase derived from the TL-6 strain play a role in alleviating salt stress in wheat. In the present study, we found that TL- 6 did produce IAA and the quantity of IAA production was increased with the salt stress increased from 0 to $20 \mathrm{mg} \mathrm{ml}^{-1}$ of salt concentration. Many other studies have also demonstrated that rhizosphere microorganisms can produce auxin alike signaling that promotes plant root branching and improves plant biomass production [4, 30-32]. Some of the rhizosphere microorganisms can help improve the fitness of plant-microbe interactions by producing IAA [33]. An added value from the present study is that the IAA production in the TL- 6 under salt stress depends on the concentration of $\mathrm{NaCl}$ solution; a low concentration of $10 \mathrm{mg} \mathrm{ml}^{-1}$ of $\mathrm{NaCl}$ stress increased IAA production significantly, and an increase of concentration to $20 \mathrm{mg}$ $\mathrm{ml}^{-1}$ had little additional effect on IAA production. In ours and other studies, the increased level of IAA production in the beneficial microorganisms may serve as an important signaling for plants to tolerate salt 
stress. The mechanisms of T. asperellum Q1 in alleviating the suppression effect of salt stress on cucumber growth involving in the ability to produce IAA, gibberellin (GA) and abscisic acid (ABA) both in the presence and absence of $\mathrm{NaCl}$, and also the levels of endogenous IAA, GA and ABA in cucumber leaves were also changed correspondingly in pot experiments [34]. Interestingly, we also found that wheat seedlings treated with the IAA producing strain of TL- 6 increased the level of IAA production significantly, as well as the expression level of two genes encoding IAA production markedly up-regulated in wheat seedling roots under salt stress condition. These findings indicate that the application of TL-6 strain significantly activated the IAA regulated genes expression that encoding IAA production significantly increased in wheat seedling roots to modulate plant growth under salt stress. Contreras-Cornejo et al. (2009), who demonstrated that the strain of $T$. virens Gv. 29-8 promotes Arabidopsis growth through auxin response pathway to modulate plant growth and activate auxin regulated gene expression [4]. However, to the best of our knowledge, this is the first report of TL-6 modulates wheat plant growth through the increased level of IAA production in TL-6 strain that induces the expression of genes encoding IAA synthesis as well as the level of IAA production in wheat seedlings roots under different levels of $\mathrm{NaCl}$ stress.

Some previous studies have also demonstrated that various biotic and abiotic stresses can cause an imbalance in ethylene biosynthesis [35-37]. The mechanisms for ethylene biosynthesis also have been reported that mainly including two main successive enzymatic reactions, (i) conversion of $\mathrm{S}$-adenosylmethionine to 1-aminocyclopropane-1-carboxylic acid by ACS, which is generally considered as the rate-limiting step in ethylene biosynthesis, and (ii) conversion of ACC to ethylene by ACO to produce ethylene in various plant organs $[38,39]$. In addition, it is common that ethylene is overproduced in plants under high salinity, and the presence of ACC-deaminase can reduce the negative consequence of ethylene on plant growth [40]. Similarly, heterologous expression of ACC-deaminase from $T$. asperellum can improve the growth performance of Arabidopsis thaliana under normal and salt stress conditions [41]. However, little is known about the mechanisms for the ACC-deaminase producing strain of TL-6 that promotes wheat seedlings growth and enhances plant tolerance to salt stress. In the present study, our results found that the increased activity of ACC-deaminase in TL-6 was observed under the concentrations of 10 and $20 \mathrm{mg} \mathrm{ml}^{-1}$ of $\mathrm{NaCl}$ solutions. Wheat seedlings treated with the ACC-deaminase producing strain of TL- 6 decreased the expression level of genes encoding ACS and ACO as well as the activity of ACO and ACS, and the content of ACC and the level of ethylene production significantly in wheat seedlings roots under salt stress condition. Similar report has been found that the strain T. asperellum T203 can produce ACC-deaminase that regulates the endogenous ACC level to reduce adverse effects of ethylene on canola (Brassica napus L.) growth [5, 42]; the strain H. seropedicae SmR1 unlike $A$. brasilense AbV5, presents a gene encoding the ACC-deaminase, which breaks ACC, the ethylene precursor in alpha-keto-butyric acid (AKB) and ammonium ion [43]; application of exogenous spermidine can reverse salinity-induced ethylene production by inhibiting the transcription and activity of ACS under salt stress [44]. Our results indicate that the promoted ACC-deaminase activity in TL- 6 by decreasing the ethylene synthesis in wheat seedlings, which served as an important signal in promoting wheat seedling growth and enhancing plant tolerance to salt stress.

In addition, previous report showed that both IAA and ACC-deaminase can stimulate plant root elongation [45]. Similarly, Gao et al. (2018) reported that the species of Pseudomonas putida and T. atroviride can modulate the regulation of IAA and ethylene in the rhizosphere and within the roots to promote the development of the root system and of the tomato (Solanum lycopersicum) plant by their ability to produce and degrade IAA, and ACC-deaminase activity in general [46]. Grave et al. (2007) found that the phytohormone of IAA produced by the microbes that can modulate the synthesis of plant ethylene, such as inhibits the transformation of ACC into ethylene by decreasing the activity of ACO [47]. Although the regulation of IAA and ethylene in the rhizosphere or within the plant roots by the microbes have been previously reported, there is little information concerning the use of TL- 6 enhanced the tolerance of wheat seedlings to salt stress at biochemical, physiological and molecular levels. Our findings suggest that the IAA and ACC-deaminase producing strain of TL-6 protects wheat plants from salt stress through the decrease of the expression level of genes encoding ACS and ACO as well as the activity of ACO and ACS, and further decreases the ACC and ethylene biosynthesis, as well as the increase of the expression level of genes encoding IAA as well as the concentration of IAA in wheat seedling roots to enhance wheat seedlings in response to salt stress.

Furthermore, a number of studies have been reported that plant cells under salt stress showed increased toxic level of cellular $\mathrm{Na}^{+}$and restricted absorption of macroelement $\mathrm{K}^{+}$, which causes a rapid reduction of $\mathrm{K}^{+} / \mathrm{Na}^{+}$ ratio in cytoplasm [48] and disturbs the intracellular ionic homeostasis in plant cells [49]. Therefore, the decreasing of $\mathrm{Na}^{+}$accumulation and maintaining a high $\mathrm{K}^{+} / \mathrm{Na}^{+}$ratio in pant tissues are considered as important mechanisms which response for plant growth and 
tolerance to salt stress $[49,50]$. In the present study, our results revealed that the $\mathrm{Na}^{+}$concentration in wheat seedlings significantly increased and that the ratio of $\mathrm{K}^{+} /$ $\mathrm{Na}^{+}$and $\mathrm{K}^{+}$concentration were decreased under salt stress. Interestingly, application of the IAA and ACC-deaminase producing strain of TL-6 alleviates the ion-specific toxicity significantly by decreasing cellular accumulation of $\mathrm{Na}^{+}$and increasing the ratio of $\mathrm{K}^{+} / \mathrm{Na}^{+}$ in both shoots and roots of wheat seedlings under $\mathrm{NaCl}$ stress. Several reports have demonstrated that the role of beneficial soil bacteria in improving plant tolerance to drought and salinity stress [51-53]. Zhang et al. (2014) found that the beneficial rhizobacterium $B$. subtilis (GB03) improved salt tolerance of wheat by decreasing $\mathrm{Na}^{+}$accumulation and increasing $\mathrm{K}^{+} / \mathrm{Na}^{+}$ratio [54]. Singh and Jha (2016) reported that application of an ACC-deaminase-producing halophilic bacterium Serratia sp. SL-12 decreased the levels of $\mathrm{Na}^{+}$by $65 \%$ and increased the $\mathrm{K}^{+}$absorbtion by $39 \%$ under salt stress [55]. Additionally, Contreras-Cornejo et al. (2014) demonstrated that Trichoderma spp. improve growth of Arabidopsis seedlings under salt stress through enhanced root development, osmolite production, and $\mathrm{Na}^{+}$elimination [27]. However, our present study showed that the IAA and ACC-deaminase producing strain of TL- 6 significantly decreased $\mathrm{Na}^{+}$accumulation and increased $\mathrm{K}^{+} /$ $\mathrm{Na}^{+}$ratio, and slightly increased $\mathrm{K}^{+}$absorption in wheat, which in line with the results from Niu et al. (2016), who reported that the strain of GB03 significantly decreased whole plant $\mathrm{Na}^{+}$content, restricted $\mathrm{K}^{+} \mathrm{ab}-$ sorption, and therefore, increased $\mathrm{K}^{+} / \mathrm{Na}^{+}$in both shoots and roots [56]. Thus, our results indicate that the strain of TL-6 enhanced salt tolerance in wheat seedlings through a reduction of $\mathrm{Na}^{+}$concentration and increasing of $\mathrm{K}^{+} / \mathrm{Na}^{+}$ratio, which play significant role in maintaining ionic homeostasis and minimizing toxic ionic effects on wheat seedlings [55].

Additionally, the regulation of ions within the cell cytosol of plants through the plasma membrane and endomembrane transporters are considered as an indispensable component of plant growth and adaptation to salinity [57]. The extra $\mathrm{Na}^{+}$ions in cytosol can be exported to extracellular through $\mathrm{Na}^{+} / \mathrm{H}^{+}$exchangers localized in the plasma membrane and to vacuole under salt stress [58]. Several important plasma membrane exchangers, such as the salt overly sensitive (SOS) pathway is essential for salt stress tolerance and maintaining ion homeostasis in the cytoplasm [59]. Among the SOS proteins, SOS1 (a plasma membrane $\mathrm{Na}^{+} / \mathrm{H}^{+}$antiporter) playing a key role in the extrusion of excess toxic $\mathrm{Na}^{+}$ from cells [60]. Similar study indicated that SOS1, a highly conserved protein in mediating $\mathrm{Na}^{+}$transportation in Arabidopsis and Puccinellia tenuiflora have important functions in regulating the cytosolic $\mathrm{Na}^{+}$efflux
[61]. Our results indicated that $\mathrm{Na}^{+} / \mathrm{H}^{+}$antiporter gene SOS1 expression was up-regulated with increasing of salt stress. Additionally, the transcript levels of SOS1 gene treated with TL-6 were significantly higher than those of the other groups, which is consistent with the improved salt tolerance and reduced $\mathrm{Na}^{+}$accumulation in shoots and roots of wheat seedlings. Also, our results indicate that SOS1 gene plays an important role in regulating the $\mathrm{Na}^{+}$transportation under high salinity, alleviating the $\mathrm{Na}^{+}$damage effects, which in line with the $\mathrm{Na}^{+} / \mathrm{H}^{+}$ exchangers in plants synergically function to cope with the extra cytosolic $\mathrm{Na}^{+}$when plants are exposed to a high-salinity condition [58].

\section{Conclusions}

Salt stress decreased the growth of wheat seedlings and the negative effect was alleviated significantly with the supplement of the beneficial microorganism Trichoderma longibrachiatum T6 (TL-6). The beneficial role of TL- 6 was reflected by the increased ACC-deaminase activity and IAA production in TL- 6 to modulate the synthesis of ethylene and IAA, $\mathrm{Na}^{+}$and the ratio of $\mathrm{K}^{+} / \mathrm{Na}^{+}$ in wheat seedlings that promote plant growth and enhance plant tolerance to salt stress; these functions were in a salt concentration dose-dependent manner. Our results revealed two possible mechanisms: (i) the promoted ACC-deaminase activity and increased IAA production in TL-6 by increasing the IAA concentration and decreasing the ethylene synthesis in wheat seedlings, which served as an important signal in alleviating the negative effect of salt stress on wheat seedlings; and (ii) the promoted ACC-deaminase activity and increased IAA production in TL- 6 by minimizing the ionic toxicity in wheat seedlings in response to salt stress.

\section{Materials and methods}

Experiments were carried out at the Gansu Provincial Biocontrol Engineering Laboratory of Crop Diseases and Pests. All treatments in the experiments described below had six replicates and each experiment was repeated twice over time, unless otherwise indicated.

\section{Fungal material}

Trichoderma longibrachiatum T6 (TL-6) was isolated from a rhizisphere saline-soil of a forest site nearby Tianshui, Gansu. The TL-6 strain was cultured on potato dextrose agar media for 5 to 6 days at $25^{\circ} \mathrm{C}$. The spore concentration in the suspension was prepared according to the procedure described previously by Zhang et al. (2014) [62]. The final spore concentration of TL- 6 was adjusted to $1 \times 10^{8}$ spores $\mathrm{ml}^{-1}$. 


\section{Seeds treatment}

The wheat (Triticum aestivum L.) cultivar 'Yongliang 4' provided by Gansu Academy of Agricultural Sciences was used in all the experiments. No any permissions were necessary to collect the plant samples. Wheat seeds with a uniform size were surface-sterilized with 1\% $\mathrm{NaOCl}$ for $5 \mathrm{~min}$ and then with $95 \%(v / \mathrm{v})$ ethanol for 5 additional minutes. After disinfection, all the seeds were rinsed with sterile water, and then were soaked in TL-6 spore suspension at the concentration of $1 \times$ $10^{8}$ spores $\mathrm{ml}^{-1}$ for $12 \mathrm{~h}$. The control seeds were soaked in sterile water for $12 \mathrm{~h}$.

\section{Effect of $\mathrm{NaCl}$ stress on colony diameter, spores production and mycelia weight of TL- 6 strain}

The different amounts of $\mathrm{NaCl}$ crystal $(0,0.2,0.4,0.6$, 0.8 and $1.0 \mathrm{~g}$ ) were added into each $20 \mathrm{ml}$ of sterilized potato dextrose agar media at $50{ }^{\circ} \mathrm{C}$, making six different concentrations of $\mathrm{NaCl}$ at $0,10,20,30,40$ and $50 \mathrm{mg} \mathrm{ml}^{-1}$, respectively. The solutions were placed on Petri dishes after $30 \mathrm{~s}$ of shaking. TL-6 mycelia discs $(5 \mathrm{~mm})$ of active culture were transferred to the centre of potato dextrose agar media plates with different concentrations of $\mathrm{NaCl}$ solutions, and were incubated at $25^{\circ} \mathrm{C}$ with supplemental day/night lighting of $16 / 8 \mathrm{~h}$. Potato dextrose agar media inoculated with TL-6 mycelia disc but not with $\mathrm{NaCl}$ solution were considered as the control $\left(0 \mathrm{mg} \mathrm{ml}^{-1}\right)$. Two days after inoculation, the colony diameter was measured daily, and the number of spore production was determined at Day 7 of incubation.

Flask culture experiments were performed using 150 $\mathrm{ml}$ of flasks that each contained $60 \mathrm{ml}$ of potato dextrose broth media and different amounts of $\mathrm{NaCl}$ crystal ( 0 , $0.6,1.2,1.8,2.4$ and $3.0 \mathrm{~g})$, and then inoculated with 1 $\mathrm{ml}$ of spore suspension of TL-6 $\left(1 \times 10^{8}\right.$ spores $\left.\mathrm{ml}^{-1}\right)$. The potato dextrose broth media inoculated with an equal amount of spore suspension of TL-6 ( $1 \mathrm{ml})$ but not with $\mathrm{NaCl}$ solution were considered as the control $\left(0 \mathrm{mg} \mathrm{ml}^{-1}\right)$. The fermentation media were incubated at $25^{\circ} \mathrm{C}$ for 5 days with shaking at $180 \mathrm{rpm} \mathrm{min}^{-1}$. At Day 5 , the fermentation was filtered using sterilized filer for three times, the mycelia were collected from the filter, oven dried at $80^{\circ} \mathrm{C}$ for $30 \mathrm{~min}$, and weighed for mycelia dry weight.

\section{IAA production in TL-6}

For the determination of the production of IAA in TL- 6 , $1 \mathrm{ml}$ of spore suspension of TL-6 $\left(1 \times 10^{8}\right.$ spores $\left.\mathrm{ml}^{-1}\right)$ was added to $100 \mathrm{ml}$ of potato dextrose broth media supplemented with L-tryptophan at $100 \mathrm{mgl}^{-1}$ in the $\mathrm{NaCl}$ concentration of 0,10 and $20 \mathrm{mg} \mathrm{ml}^{-1}$. The fermentation broth was grown in shaker at $180 \mathrm{rpm} \mathrm{min}^{-1}$ for 5 days at $28^{\circ} \mathrm{C}$, centrifuged at $10,000 \mathrm{~g}$ for $20 \mathrm{~min}$ at
$4{ }^{\circ} \mathrm{C}$, and the culture was filtrated through a Whattman Paper No.3 filter and followed by filtration through $0.22 \mu \mathrm{m}$ Millipore membranes. IAA concentration was determined according to the method of Salkowski reagent [63]. The concentration of IAA was determined by comparison with a standard curve prepared in an IAA standard curve.

\section{ACC-deaminase activity determination in TL-6}

For the determination of the ACC-deaminase activity of TL- 6 under salt stress, $1 \mathrm{ml}$ of spore suspension of TL- 6 $\left(1 \times 10^{8}\right.$ spores $\left.\mathrm{ml}^{-1}\right)$ was inoculated in $60 \mathrm{ml}$ of synthetic medium [64] in the 0,10 and $20 \mathrm{mg} \mathrm{ml}^{-1}$ of $\mathrm{NaCl}$ solutions. The culture was grown at $28^{\circ} \mathrm{C}$ with shaking at $180 \mathrm{rpm} \mathrm{min}{ }^{-1}$ for 5 days. At Day 5 of incubation, the mycelia were collected and suspended in $2.5 \mathrm{ml}$ of Tris buffer $(0.1 \mathrm{M}, \mathrm{pH} 8.5)$, and homogenized for $30 \mathrm{~s}$. Afterwards, $25 \mu \mathrm{l}$ of toluene was added to a $200 \mu \mathrm{l}$ aliquot and vortexed vigorously for $30 \mathrm{~s}$, and then $20 \mu \mathrm{l}$ of $0.5 \mathrm{M}$ solution of ACC was added in the mixtures (no ACC added in the control). After an incubation period at $30^{\circ} \mathrm{C}$ for $15 \mathrm{~min}, 1 \mathrm{ml}$ of $0.56 \mathrm{~N} \mathrm{HCl}$ was added and the reaction mixtures were centrifuged at $10,000 \mathrm{~g}$ for $10 \mathrm{~min}$, and then $1 \mathrm{ml}$ of the supernatant was mixed with $800 \mu \mathrm{l}$ of $0.56 \mathrm{~N} \mathrm{HCl}$ and $300 \mu \mathrm{l}$ of 2, 4-dinitrophenylhydrazine. Thereafter, $2 \mathrm{ml}$ of $2 \mathrm{~N} \mathrm{NaOH}$ was added to the mixtures after an incubation period at $30{ }^{\circ} \mathrm{C}$ for $30 \mathrm{~min}$. ACC-deaminase activity was evaluated quantitatively by measuring the amount of a-ketobutyrate produced by the deamination of ACC according to the method of Viterbo et al. [5], and was expressed as $\mu \mathrm{mol}$ a-ketobutyrate $\mathrm{mg}^{-1}$ protein $\mathrm{h}^{-1}$.

Effect of IAA and ACC-deaminase producing strain of TL-6 on wheat seedling tolerance to $\mathrm{NaCl}$ stress in greenhouse Wheat seeds (80 seeds) with a uniform size were planted in $10-\mathrm{cm}$ diameter pots that contained $300 \mathrm{~g}$ of sterilized soil. A total of 50 seedlings per pot were kept through thinning at Day 12 after emergence. The experiments included two group treatments: (i) wheat seeds were soaked with the spore suspension of TL-6 and inoculated at 0,10 and $20 \mathrm{mg} \mathrm{ml}^{-1}$ of $\mathrm{NaCl}$ concentrations, and (ii) wheat seeds were soaked with sterile water and inoculated at 0,10 and $20 \mathrm{mg} \mathrm{ml}^{-1}$ of $\mathrm{NaCl}$ concentrations. Each of the $\mathrm{NaCl}$-treated pots was irrigated with $25 \mathrm{ml}$ of $\mathrm{NaCl}$ solution whereas the $0 \mathrm{mg} \mathrm{ml}^{-1}$ of $\mathrm{NaCl}$ concentration treatment was irrigated with $25 \mathrm{ml}$ of sterile water. Plants were grown in a greenhouse $\left(25^{\circ} \mathrm{C}\right)$ with supplemental day/night lighting of $16 / 8 \mathrm{~h}$, and each pot was irrigated with $200 \mathrm{ml}$ of sterile distilled water at regular intervals. The seedlings biochemical, physiological and molecular parameters were determined at Day 35. 
Extraction and determination of IAA production in wheat seedling under $\mathrm{NaCl}$ stress

For the determination of the concentration of IAA in wheat seedlings, roots samples ( $1 \mathrm{~g})$ of 35 -day-old wheat seedlings were frozen immediately and then homogenized with a mortar and pestle using $80 \%$ methanol. The pulverized mixture was stirred overnight at $4{ }^{\circ} \mathrm{C}$, and the impurities were then removed by centrifuging at 10, 000 $\mathrm{g}$ for $20 \mathrm{~min}$. The supernatant was filtrated and used to analyze the level of IAA production by high performance liquid chromatography [65].

\section{Assay of ACO and ACS activity in wheat seedling under $\mathrm{NaCl}$ stress}

For the determination of the activity of ACO and ACS, wheat seedling roots samples of $1 \mathrm{~g}$ were frozen immediately and ground to a fine powder, and then added to $5.0 \mathrm{ml}$ of an extraction buffer. Thereafter, the homogenate was centrifuged at $12,000 \mathrm{~g}$ for $10 \mathrm{~min}$ and then the supernatant was used for ACO and ACS activity assay.

The activity of ACO was assayed according to the procedure described previously by Kato et al. (2000) with some modifications [66]. The purified supernatant was incubated in $2 \mathrm{ml}$ reaction medium for $1 \mathrm{~h}$ at $30^{\circ} \mathrm{C}$, and then a sample of $2 \mathrm{ml}$ gas was collected and used to determine the ethylene level on a gas chromatograph. The activity of ACO was determined as the amount of ethylene converted from ACC during the reaction period, and expressed as nanomoles ACC per gram protein per hour.

The activity of ACS was assayed according to the procedure described previously by Fan et al. (1998) with some modifications [67]. ACS activity was measured by incubating $2.0 \mathrm{ml}$ of purified supernatant in a reaction mixture at $30^{\circ} \mathrm{C}$ for $1 \mathrm{~h}$. Thereafter, one milliliter of headspace gas sample was collected and injected into a gas chromatograph for ethylene assay. ACS activity was determined as the amount of ethylene converted from SAM during the reaction period, and expressed as nanomoles ACC per gram protein per hour.

\section{Determination of ACC content and ethylene synthesis in wheat seedling under $\mathrm{NaCl}$ stress}

ACC extraction was extracted by a solid-phase extraction procedure according to the method described by Madhaiyan et al. (2007) [68]. Wheat seedling roots samples of $1 \mathrm{~g}$ were frozen in liquid nitrogen and ground to a fine powder, and then $1 \mathrm{ml}$ of the gaseous portion was taken and assayed for ethylene synthesis by gas chromatography. ACC content was expressed as micromoles per gram fresh weight per hour [69].

Ethylene level was determined following the method of Yamauchi et al. (2014) with some modifications [70]. Roots samples of wheat seedlings $(1 \mathrm{~g})$ were placed in a container and ground to a fine powder with saturated sodium chloride solution. One milliliter of collected gas sample was used to measure the ethylene level by gas chromatography. Ethylene production was expressed as nanomoles per gram fresh weight per hour.

\section{Determination of $\mathrm{Na}^{+}$and $\mathrm{K}^{+}$concentration in wheat seedling under $\mathrm{NaCl}$ stress}

For the determination of $\mathrm{Na}^{+}$and $\mathrm{K}^{+}$concentrations in plant tissues, wheat seedlings in each treatment were thoroughly washed three times with deionized water to remove surface salts, and then dried with absorbent paper. The shoots and roots were separated and oven dried at $65^{\circ} \mathrm{C}$ for 2 days. The dried shoots and roots of $0.4 \mathrm{~g}$ were extracted with $20 \mathrm{ml}$ of $100 \% \mathrm{HNO}_{3}$ for $24 \mathrm{~h}$, respectively, followed by incubation at $90{ }^{\circ} \mathrm{C}$ for $2 \mathrm{~h}$. Thereafter, the digested samples and the solutions were filtered, and then the filtrates were diluted with sterile water to 10 -fold. The concentrations of $\mathrm{K}^{+}$and $\mathrm{Na}^{+}$were determined by an atomic absorption spectrophotometry [52, 54].

\section{Total RNA extraction and first strand CDNA synthesis}

Total RNA was extracted from the wheat seedlings of 35 days of old (200 mg sample) in all treatments including those treated with the IAA and ACC-deaminase producing strain of TL- 6 or sterile water under different concentrations of $\mathrm{NaCl}$ solutions $\left(0,10\right.$ and $\left.20 \mathrm{mg} \mathrm{ml}^{-1}\right)$. The extraction was conducted by following the manufacturer's

Table 2 DNA sequences of qRT-PCR primers for the determination of the level of ethylene and IAA synthesis gene expression in wheat seedlings

\begin{tabular}{|c|c|}
\hline Genes & Premiers sequence $\left(5^{\prime}-3^{\prime}\right)$ \\
\hline \multirow[t]{2}{*}{ TaTGW6 } & F: CACCTCGTGGTCGCATCT \\
\hline & R: ATCTGGGTAGCCCGGCAG \\
\hline \multirow[t]{2}{*}{ TaIAGLU } & F: CGTGTTCGCGCTCAGCCAGT \\
\hline & R: CGAGGGACGCGAAGCTGCCG \\
\hline \multirow[t]{2}{*}{ TaACO } & F: CCTACCCGAGGTTCGTGTT \\
\hline & R: CTCCTTGGCCTCGAACTTGT \\
\hline \multirow[t]{2}{*}{ TaACO1 } & F: TCCCAGGTTTGGAGTTTCTG \\
\hline & R: ATAGATAGGCGGCTCCCATT \\
\hline \multirow[t]{2}{*}{$\mathrm{TaACO} 2$} & F: CCTACCCGAGGTTCGTGTT \\
\hline & R: CTCCTTGGCCTCGAACTTGT \\
\hline \multirow[t]{2}{*}{ TaACS } & F: GATCTCCATGGTCTGGTCGT \\
\hline & R: CTCTTCTCGTGGATGGACCT \\
\hline \multirow[t]{2}{*}{ TaACS1 } & F: GAATTCGAT GGTGAGCCAAGT \\
\hline & R: AGCGCGTGGGGGTTCTTCT \\
\hline \multirow[t]{2}{*}{ TaACS7 } & F: GAGGTGAAGCTCAACATCTCG \\
\hline & R: TGTTCTTGCTGCGTTGACAT \\
\hline \multirow[t]{2}{*}{ Actin } & F: AGCCATACTGTGCCAATC \\
\hline & R: GCAGTGGTGGTGAAGGAGTAA \\
\hline
\end{tabular}

Note: $F$ represents forward, $R$ represents reverse 
instruction of Tiangen RNA Simple Total RNA Kit (Tiangen Biotechnology, Beijing, China). The first-strand cDNA was synthesized according to the procedure described previously by Zhang et al. (2016) [24].

\section{Quantitative real-time PCR (qRT-PCR) analysis}

Genes encoding ethylene and IAA synthesis, and $\mathrm{Na}^{+} / \mathrm{H}^{+}$antiporter were identified in wheat seedlings after treated with the IAA and ACC-deaminase producing strain of TL- 6 or sterile water under different concentrations of $\mathrm{NaCl}$ solutions. qRT-PCR was performed using a SYBR Premix Ex Taq kit (Takara Biotechnology, Dalian, China) following the manufacturer's instruction. Specific primer for each gene (TaTGW6, TaIAGLU, TaACO, TaACO1, TaACO2, TaACS, TaACS1, TaACS7, SOS1 and Actin genes) was designed according to the EST sequences of wheat in NCBI $[46,65,71]$ using Primer Express 5.0 software that amplifies the target genes (Table 2). The Actin gene of wheat was used as an internal control. The relative expression of TaTGW6, TaIAGLU, TaACO, TaACO1, TaACO2, TaACS, TaACS1, TaACS7 and SOS1 genes was determined using the method of $2^{-\Delta \Delta \mathrm{Ct}}$ [72]. All treatments had six replicates and was repeated twice, thus, the gene expression was the average value of twelve independent replicates.

\section{Statistical analysis}

A factorial design was applied to all the experiments in the study. The factors tested in each experiment included TL- 6 or sterile water treatments at the different levels of salt stress. Each experiment had six replications and was repeated twice over time. The data were subject to ANOVA using SPSS Version 16.0 (SPSS Inc., Chicago, IL). Preliminary analysis showed that there were no significant interactions between the two runs and treatments, and thus the data from the two runs of experiments were pooled together in the ANOVA. The significance between the treatments was considered at the level of $P<0.05$. Duncan's new multiple range test values were computed using standard error and T-values of adjusted degrees of freedom.

\footnotetext{
Abbreviations

ABA: abscisic acid; ACC: 1-aminocyclopropane-1-carboxylate; ACCdeaminase: 1-aminocyclopropane-1-carboxylate-deaminase; ACO: ACC oxidase; ACS: ACC synthase; FW: Fresh weight; GA: gibberellin; IAA: Indole acetic acid; SAM: S-adenosylmethionin; SOS: Salt overly sensitive; TL6: Trichoderma longibrachiatum T6
}

\section{Acknowledgments}

The authors would like to thank Dr. Alejandro Calderón-Urrea (Professor of Developmental Biology, California State University, Fresno) and Dr. Yingyu Xue (Professor of Plant Pathology, Gansu Agricultural University, China) for their helpful discussion and critical review of the manuscript.

\section{Funding}

This work was supported by Special Funds for Discipline Construction (project GAU-XKJS-2018-147); Research Program Sponsored by Gansu Provincial Key Laboratory of Aridland Crop Science, Gansu Agricultural University (project GSCS-2017-1); Scientific Research Start-up Funds for Openly-recruited Doctors (project 2017RCZX-07); National Natural Science Foundation of China (project 31860526); Gansu Provincial Science Fund for Distinguished Young Scholars (project 18JR3RA161); International Scientific and Technological Cooperation of Gansu Province (project 1604WKCA010) and Hall of Gansu Province Farming Herd Biology Technology (project GNSW-2013-19). The above funding to SZ and BX was used for the design of the study and collection, analysis, and interpretation of data in writing the manuscript.

\section{Availability of data and materials \\ Not applicable.}

\section{Authors' contributions}

SZ and BX conceived the experiments with the help of YG. SZ collected and prepared the fungus and wheat seedling samples, and performed the effect of $\mathrm{NaCl}$ stress on the strain of TL-6 growth experiments and extracted the total RNA from wheat seedling samples. YG and SZ performed qRT-PCR, analyzed the data, and interpreted the results. SZ wrote the manuscript. $S Z, Y G$ and BX revised and approved the final manuscript.

Ethics approval and consent to participate

Not applicable.

\section{Consent for publication}

Not applicable.

\section{Competing interests}

The authors declare that they have no competing interests.

\section{Publisher's Note}

Springer Nature remains neutral with regard to jurisdictional claims in published maps and institutional affiliations.

\section{Author details \\ ${ }^{1}$ Gansu Provincial Key Laboratory of Arid Land Crop Science, Gansu Agricultural University/College of Plant protection, Gansu Agricultural University/ Biocontrol Engineering Laboratory of Crop Diseases and Pests of Gansu Province, Lanzhou 730070, China. ${ }^{2}$ Agriculture and Agri-Food Canada/ Government of Canada Swift Current Research \& Development Centre, Swift Current, Saskatchewan SK S9H 3X2, Canada.}

Received: 27 October 2018 Accepted: 26 December 2018

Published online: 11 January 2019

\section{References}

1. Zhang SW, Gan YT, Xu BL. Efficacy of Trichoderma longibrachiatum in the control of Heterodera avenae. BioControl. 2014;59:319-31.

2. López-Bucio J, Pelagio-Flores R, Herrera-Estrella A. Trichoderma as biostimulant: exploiting the multilevel properties of a plant beneficial fungus. Sci Hortic. 2015;196:109-23.

3. Brotman Y, Landau U, Cuadros-Inostroza A, Takayuki T, Fernie AR, Chet I, Viterbo A, Willmitzer L. Trichoderma-plant root colonization: escaping early plant defense responses and activation of the antioxidant machinery for saline stress tolerance. PLoS Pathog. 2013;9(3):130-9.

4. Contreras-Cornejo HA, Macías-Rodríguez L, Cortés-Penagos C, López-Bucio J. Trichoderma virens, a plant beneficial fungus, enhances biomass production and promotes lateral root growth through an auxin-dependent mechanism in Arabidopsis. Plant Physiol. 2009;149:1579-92.

5. Viterbo A, Landau U, Kim S, Chernin L, Chet I. Characterization of ACC deaminase from the biocontrol and plant growth-promoting agent Trichoderma asperellum T203. FEMS Microbiol Lett. 2010;305:42-8.

6. Bal HB, Nayak L, Das S, Adhya TK. Isolation of ACC deaminase producing PGPR from rice rhizosphere and evaluating their plant growth promoting activity under salt stress. Plant Soil. 2013;366:93-105.

7. Harman GE. Overview of mechanisms and uses of Trichoderma spp. Phytopathology. 2006;96:190-4. 
8. Hoitink HAJ, Madden LV, Dorrance AE. Systemic resistance induced by Trichoderma spp.: interactions between the host, the pathogen, the biocontrol agent, and soil organic matter quality. Phytopathology. 2006;96:186-9.

9. Gachomo EW, Kotchoni SO. The use of Trichoderma harzianum and Trichoderma viride as potential biocontrol agents against peanut microflora and their effectiveness in reducing aflatoxin contamination of infected kernels. Biotechnol. 2008;7:439-47.

10. Li JT, Qiu ZB, Zhang XW, Wang LS. Exogenoushy drogen peroxide can enhance tolerance of wheat seedlings to salt stress. Acta Physiol Plant. 2011;33:835-42.

11. Rawat $L$, Singh $Y$, Shukla N, Kumar J. Alleviation of the adverse effects of salinity stress in wheat (Triticum aestivum L.) by seed biopriming with salinity tolerant isolates of Trichoderma harzianum. Plant Soil. 2011;347:387-400

12. Wu HF, Liu XL, You LP, Zhang LB, Zhou D, Feng JH, Zhao JM, Yu JB. Effects of salinity on metabolic profiles, gene expressions and antioxidant enzymes in halophyte Suaeda salsa. J Plant Growth Regul. 2012;31:332-41.

13. Qi WZ, Zhao L. Study of the siderophore-producing Trichoderma asperellum Q1 on cucumber growth promotion under salt stress. J Basic Microbiol. 2013;53(4):355-64.

14. Fang $P$, Ren $L L$, Zhang $L T$. Inhibition effects of salt stress on photosynthetic activity of Rumex K-1. Chin J Appl Ecol. 2008;19(10):2137-42.

15. Essah PA, Davenport R, Tester M. Sodium influx and accumulation in Arabidopsis. Plant Physiol. 2003;133:307-18.

16. Katori T, Ikeda A, luchi S, Kobayashi M, Shinozaki K, Maehashi K, Sakata Y, Tanaka S, Taji T. Dissecting the genetic control of natural variation in salt tolerance of Arabidopsis thaliana accessions. J Exp Bot. 2010;61:1125-38.

17. Glick BR. Promotion of plant growth by bacterial ACC deaminase. Crit Rev Plant Sci. 2007;26:227-42.

18. Talaat NB, Shawky BT. Influence of arbuscular mycorrhizae on yield, nutrients, organic solutes, and antioxidant enzymes of two wheat cultivars under salt stress. J Plant Nutr Soil Sci. 2011;174:283-91.

19. Abdel-Fattah GM, Asrar AA. Arbuscular mycorrhizal fungal application to improve growth and tolerance of wheat (Triticum aestivum L.) plants grown in saline soil. Acta Physiol Plant. 2012;34:267-77.

20. Cekic FO, Unyayar S, Ortas I. Effects of arbuscular mycorrhizal inoculation on biochemical parameters in Capsicum annuum grown under long term salt stress. Turk J Bot. 2012;36:63-72.

21. Talaat NB, Shawky BT. Modulation of the ROS-scavenging system in saltstressed wheat plants inoculated with arbuscular mycorrhizal fungi. J Plant Nutr Soil Sci. 2014;177:199-207.

22. Mastouri F, Björkman T, Harman GE. Seed treatment with Trichoderma harzianum alleviates biotic, abiotic, and physiological stresses in germinating seeds and seedlings. Phytopathology. 2010;100:1213-21.

23. Ahmad P, Hashem A, Abd-Allah EF, Alqarawi AA, John R, Egamberdieva D, Gucel S. Role of Trichoderma harzianum in mitigating $\mathrm{NaCl}$ stress in Indian mustard (Brassica juncea L.) through antioxidative defense system. Front Plant Sci. 2015;6:868.

24. Zhang SW, Gan YT, Xu BL. Application of plant-growth-promoting fungi Trichoderma longibrachiatum T6 enhances tolerance of wheat to salt stress through improvement of antioxidative defense system and gene expression. Front Plant Sci. 2016;7:1405.

25. Harman GE, Howell CR, Viterbo A, Chet I, Lorito M. Trichoderma speciesopportunistic, avirulent plant symbionts. Nat Rev Microbiol. 2004;2:43-56.

26. Henk GA, Cuppers ML. A model for the combined effects of temperature and salt concentration on growth rate of food spoilage molds. Appl Environ Microb. 1997;63(10):3764-9.

27. Contreras-Cornejo HA, Macías-Rodríguez L, Alfaro-Cuevas R, López-Bucio J. Trichoderma spp. improve growth of Arabidopsis seedlings under salt stress through enhanced root development, osmolite production, and $\mathrm{Na}^{+}$ elimination through root exudates. Mol Plant-Microbe Interact. 2014;27:503-14

28. Wilson JM, Griffin DM. The effect of water potential on the growth of some solid basidiomycetes. Soil Biol Biochem. 1979;11:211-2.

29. Yeo AR. Salinity resistance: physiologies and prices. Physiol Plantarum. 1983; 58:214-22.

30. Ortíz-Castro R, Díaz-Pérez C, Martínez-Trujillo M, del Rio RE, Campos-Garcia J, Lopez-Bucio J. Trans kingdom signaling based on bacterial cyclodipeptides with auxin activity in plants. Proc Natl Acad Sci U S A. 2011;108:7253-8.

31. Felten J, Martin F, Legue V. Signalling in ectomycorrhizal symbiosis. Signal Commun Plants. 2012;10:123-42.
32. Hilbert M, Lars M, Yi D, Hofmann J, Sharma M, Zuccaro A. Indole derivative production by the root endophyte Piriformospora indica is not required for growth promotion but for biotrophic colonization of barley roots. New Phytol. 2012;196:520-34.

33. Patten $\mathrm{CL}$, Glick BR. Role of Pseudomonas putida indole acetic acid in development of the host plant root system. Appl Environ Microbiol. 2002;68:3795-801.

34. Zhao L, Zhang YQ. Effects of phosphate solubilization and phytohormone production of Trichoderma asperellum Q1 on promoting cucumber growth under salt stress. J Integr Agr. 2015;14(8):1588-97.

35. Bacilio M, Rodriguez H, Moreno M, Hernandez JP, Bashanand Y. Mitigation of salt stress in wheat seedlings by a gfp-tagged Azospirillum lipoferum. Biol Fertil Soils. 2004;40:188-93.

36. Cheng ZCZ, Park EPE, Glick BRGBR. 1-Aminocyclopropane-1-carboxylate deaminase from Pseudomonas putida UW4 facilitates the growth of canola in the presence of salt. Can J Microbiol. 2007;53:912-8.

37. Zahir ZA, Ghani U, Naveed M, Nadeem SM, Asghar HN. Comparative effectiveness of Pseudomonas and Serratia sp. containing ACC-deaminase for improving growth and yield of wheat (Triticum aestivum L.) under salt-stressed conditions. Arch Microbiol. 2009;191:415-24.

38. Yang SF, Hoffman NE. Ethylene biosynthesis and its regulation in higher plants. Annu Rev Plant Physiol. 1984;35:155-89.

39. Bleecker $A B$, Kende H. Ethylene: a gaseous signal molecule in plants. Annu Rev Cell Dev Biol. 2000;16:1-18.

40. Gamalero E, Berta G, Massa N, Glick BR, Lingua G. Interactions between Pseudomonas putida UW4 and Gigaspora rosea BEG9 and their consequences for the growth of cucumber under salt-stress conditions. J Appl Microbiol. 2010;108:236-45.

41. Zhan FL, Zhang J, Chen L, Shi XY, Lui ZH, Li CW. Heterologous expression of ACC-deaminase from Trichoderma asperellum improves the growth performance of Arabidopsis thaliana under normal and salt stress conditions. Plant Physiol Bioch. 2015;94:41-7.

42. Abels FB, Morgan PW, Saltveit ME. Ethylene in plant biology. New York: Academic Press; 1992.

43. Volpiano CG, Estevam A, Saatkamp K, Furlan F, Vendruscolo ECG, Santos MFD. Physiological responses of the co-cultivation of PGPR with two wheat cultivars in vitro under stress conditions. BMC Proc. 2014;8:108.

44. Li B, Sang T, He LZ, Sun J, Li J, Guo SR. Exogenous spermidine inhibits ethylene production in leaves of cucumber seedlings under $\mathrm{NaCl}$ stress. J Amer Soc Hort Sci. 2013;138:108-13.

45. Ali S, Charles TC, Glick BR. Amelioration of high salinity stress damage by plant growth-promoting bacterial endophytes that contain ACC-deaminase. Plant Physiol Bioch. 2014;80:160-7.

46. Gao Y, Li J, Pan XK, Liu DR, Napierc R, Dong LY. Quinclorac resistance induced by the suppression of the expression of 1-aminocyclopropane-1carboxylic acid (ACC) synthase and ACC oxidase genes in Echinochloa crusgalli var Zelayensis. Pestic Biochem Phys. 2018;146:25-32.

47. Gravel V, Antoun H, Tweddell RJ. Growth stimulation and fruit yield improvement of greenhouse tomato plants by inoculation with Pseudomonas putida or Trichoderma atroviride: possible role of indole acetic acid (IAA). Soil Biol Biochem. 2007;39:1968-77.

48. Tester M, Davenport R. $\mathrm{Na}^{+}$tolerance and transport in higher plants. Ann Bot. 2003;91:503-27.

49. Chen Z, Pottosin II, Cuin TA, Fuglsang AT, Tester M, Jha D, Zepeda-Jazo I, Zhou M, Palmgren MG, Newman IA, Shabala S. Root plasma membrane transporters controlling $\mathrm{K}^{+} / \mathrm{Na}^{+}$homeostasis in salt-stressed barley. Plant Physiol. 2007; 145:1714-25.

50. Deng YQ, Bao J, Yuan F, Liang X, Feng ZT, Wang BS. Exogenous hydrogen sulfide alleviates salt stress in wheat seedlings by decreasing $\mathrm{Na}^{+}$content. Plant Growth Regul. 2016;79:391-9.

51. Cho SM, Kang BR, Han SH, Anderson AJ, Park JY, Lee YH, Cho BH, Yang KY, Ryu CM, Kim YC. 2R, 3R-butanediol, a bacterial volatile produced by Pseudomonas chlororaphis O6, is involved in induction of systemic tolerance to drought in Arabidopsis thaliana. Mol Plant-Microbe Interact. 2008;21:1067-75.

52. Zhang H, Kim MS, Sun Y, Dowd SE, Shi H, Paré PW. Soil bacteria confer plant salt tolerance by tissue-specific regulation of the sodium transporter HKT1. Mol Plant-Microbe Interact. 2008;21(6):737-44.

53. Belimov AA, Dodd IC, Hontzeas N, Theobald JC, Safronova VI, Davies WJ. Rhizosphere bacteria containing 1-aminocyclopropane-1-carboxylate deaminase increase yield of plants grown in drying soil via both local and systemic hormone signalling. New Phytol. 2009;181(2):413-23. 
54. Zhang JL, Aziz M, Qiao Y, Han QQ, Li J, Wang YQ, Shen X, Wang SM, Pare PW. Soil microbe Bacillus subtilis (GBO3) induces biomass accumulation and salt tolerance with lower sodium accumulation in wheat. Crop Pasture Sci. 2014:65(5):423-7.

55. Singh RP, Jha PN. Alleviation of salinity-induced damage on wheat plant by an ACC deaminase-producing halophilic bacterium Serratia sp. SL-12 isolated from a salt lake. Symbiosis. 2016;69:101-11.

56. Niu SQ, Li HR, Paré PW, Aziz M, Wang SM, Shi HZ, Li J, Han QQ, Guo SQ, Li JA, Guo Q, Ma Q, Zhang JL. Induced growth promotion and higher salt tolerance in the halophyte grass Puccinellia tenuiflora by beneficial rhizobacteria. Plant Soil. 2016:407:217-30.

57. Cheng NH, Pittman JK, Zhu JK, Hirschi KD. The protein kinase SOS2 activates the Arabidopsis $\mathrm{H}^{+} / \mathrm{Ca}^{2+}$ antiporter $\mathrm{CAX} 1$ to integrate calcium transport and salt tolerance. J Biol Chem. 2004;279:2922-6.

58. Yamaguchi T, Hamamoto S, Uozumi N. Sodium transport system in plant cells. Front Plant Sci. 2013;4:410.

59. Zhu JK. Salt and drought stress signal transduction in plants. Annu Rev Plant Biol. 2002;53:247-73.

60. Feki K, Quintero FJ, Khoudi H, Leidi EO, Masmoudi K, Pardo JM, Brini F. A constitutively active form of a durum wheat $\mathrm{Na}^{+} / \mathrm{H}^{+}$antiporter SOS1 confers high salt tolerance to transgenic Arabidopsis. Plant Cell Rep. 2014;33:277-88

61. Qiu QS, Guo Y, Dietrich MA, Schumaker KS, Zhu JK. Regulation of SOS1, a plasma membrane $\mathrm{Na}^{+} / \mathrm{H}^{+}$exchanger in Arabidopsis thaliana, by SOS2 and SOS3. Proc Natl Acad Sci. 2002;99:8436-41.

62. Zhang SW, Gan YT, Xue YY, Xu BL. The parasitic and lethal effects of Trichoderma longibrachiatum against Heterodera avenae. Biol Control. 2014;72:1-8.

63. Glickmann E, Dessaux Y. A critical examination of the specificity of the Salkowski reagent for indolic compounds produced by phytopathogenic bacteria. Appl Environ Microbiol. 1995;61:793-6.

64. Yedidia I, Benhamou N, Chet I. Induction of defense responses in cucumber plants (Cucumis sativus L.) by the biocontrol agent Trichoderma harzianum. Appl Environ Microbiol. 1999;65:1061-70.

65. Hu MJ, Zhang HP, Cao JJ, Zhu XF, Wang SX, Jiang H, Wu ZY, Lu J, Chang C, Sun GL, Ma CX. Characterization of an IAA-glucose hydrolase gene TaTGW6 associated with grain weight in common wheat (Triticum aestivum L.). Mol Breeding. 2016;36(3):25.

66. Kato M, Hayakawa Y, Hyodo H, Ikoma Y, Yano M. Wound-induced ethylene synthesis and expression and formation of 1-aminocyclopropane-1carboxylate (ACC) synthase, ACC oxidase, phenylalanine ammonia-lyase, and peroxidase in wounded mesocarp tissue of Cucurbita maxima. Plant Cell Physiol. 2000;41:440-7.

67. Fan X, Mattheis JP, Fellman JK. A role for jasmonates in climacteric fruit ripening. Planta. 1998;204(4):444-9.

68. Madhaiyan M, Poonguzhali S, Sa TM. Characterization of 1aminocyclopropane-1-carboxylate (ACC) deaminase containing Methylobacteriumoryzae and interactions with auxins and ACC regulation of ethylene in canola (Brassica campestris). Planta. 2007;226:867-76.

69. Barnawal D, Bharti N, Maji D, Chanotiya CS, Kalra A. 1-Aminocyclopropane-1carboxylic acid (ACC) deaminase-containing rhizobacteria protect Ocimum sanctum plants during water logging stress via reduced ethylene generation. Plant Physiol Biochem. 2012;58:227-35.

70. Yamauchi T, Watanabe K, Fukazawa A, Mori H, Abe F, Kawaguchi K, Oyanagi A, Nakazono M. Ethylene and reactive oxygen species are involved in root aerenchyma formation and adaptation of wheat seedlings to oxygendeficient conditions. J Exp Bot 2014; 65(1): 261-73.

71. Qiu ZB, Guo JL, Zhu AJ, Zhang L, Zhang MM. Exogenous jasmonic acid can enhance tolerance of wheat seedlings to salt stress. Ecotox Environ Safe. 2014;104:202-8.

72. Livak KJ, Schmittgen TD. Analysis of relative gene expression data using real-time quantitative PCR and the $2^{-\Delta \Delta \mathrm{Ct}}$ method. Methods. 2001;25:402-8.

\section{Ready to submit your research? Choose BMC and benefit from:}

- fast, convenient online submission

- thorough peer review by experienced researchers in your field

- rapid publication on acceptance

- support for research data, including large and complex data types

- gold Open Access which fosters wider collaboration and increased citations

- maximum visibility for your research: over $100 \mathrm{M}$ website views per year

At BMC, research is always in progress.

Learn more biomedcentral.com/submissions 